\title{
Geomorphic analysis of transient landscapes in the Sierra Madre de Chiapas and Maya Mountains (northern Central America): implications for the North American-Caribbean-Cocos plate boundary
}

\author{
L. Andreani ${ }^{1,2}$ and R. Gloaguen ${ }^{1,2}$ \\ ${ }^{1}$ TU Bergakademie Freiberg, Institut für Geologie, Freiberg, Germany \\ ${ }^{2}$ Division of Exploration Technology, Helmholtz Institute Freiberg for Resource Technology, \\ Freiberg, Germany
}

Correspondence to: L. Andreani (louis.andreani@googlemail.com) and R. Gloaguen (r.gloaguen@hzdr.de)

Received: 27 August 2015 - Published in Earth Surf. Dynam. Discuss.: 15 September 2015

Revised: 22 December 2015 - Accepted: 4 January 2016 - Published: 21 January 2016

\begin{abstract}
We use a geomorphic approach in order to unravel the recent evolution of the diffuse triple junction between the North American, Caribbean, and Cocos plates in northern Central America. We intend to characterize and understand the complex tectonic setting that produced an intricate pattern of landscapes using tectonic geomorphology, as well as available geological and geophysical data. We classify regions with specific relief characteristics and highlight uplifted relict landscapes in northern Central America. We also analyze the drainage network from the Sierra Madre de Chiapas and Maya Mountains in order to extract information about potential vertical displacements.

Our results suggest that most of the landscapes of the Sierra Madre de Chiapas and Maya Mountains are in a transient stage. Topographic profiles and morphometric maps highlight elevated relict surfaces that are characterized by a low-amplitude relief. The river longitudinal profiles display upper reaches witnessing these relict landscapes. Lower reaches adjust to new base-level conditions and are characterized by multiple knickpoints.

These results backed by published GPS and seismotectonic data allow us to refine and extend existing geodynamic models of the triple junction. Relict landscapes are delimited by faults and thus result from a tectonic control. The topography of the Sierra Madre de Chiapas evolved as the result of (1) the inland migration of deformation related to the coupling between the Chiapas Massif and the Cocos forearc sliver and (2) the compression along the northern tip of the Central American volcanic arc. Although most of the shortening between the Cocos forearc sliver and the North American Plate is accommodated within the Sierra de Chiapas and Sierra de los Cuchumatanes, a small part may be still transmitted to the Maya Mountains and the Belize margin through a "rigid" Petén Basin.
\end{abstract}

\section{Introduction}

The aim of this work is to examine geomorphic features along two key areas (the Sierra Madre de Chiapas and the Maya Mountains, Fig. 1) in order to test existing models of the North American-Caribbean-Cocos plate boundary (e.g., Malfait and Dinkelman, 1972; Burkart, 1983; GuzmánSpeziale et al., 1989; Lyon-Caen et al., 2006; Ratschbacher et al., 2009; Authemayou et al., 2011). The oceanic Cocos Plate is subducted beneath the North American and Caribbean plates along the Middle America Trench, while the North American-Caribbean plate boundary is a sinistral transform system which accommodates the eastward escape of the Caribbean Plate (e.g., Lyon-Caen et al., 2006; Manea and Manea, 2006; Andreani et al., 2008a; Authemayou et al., 2011). 


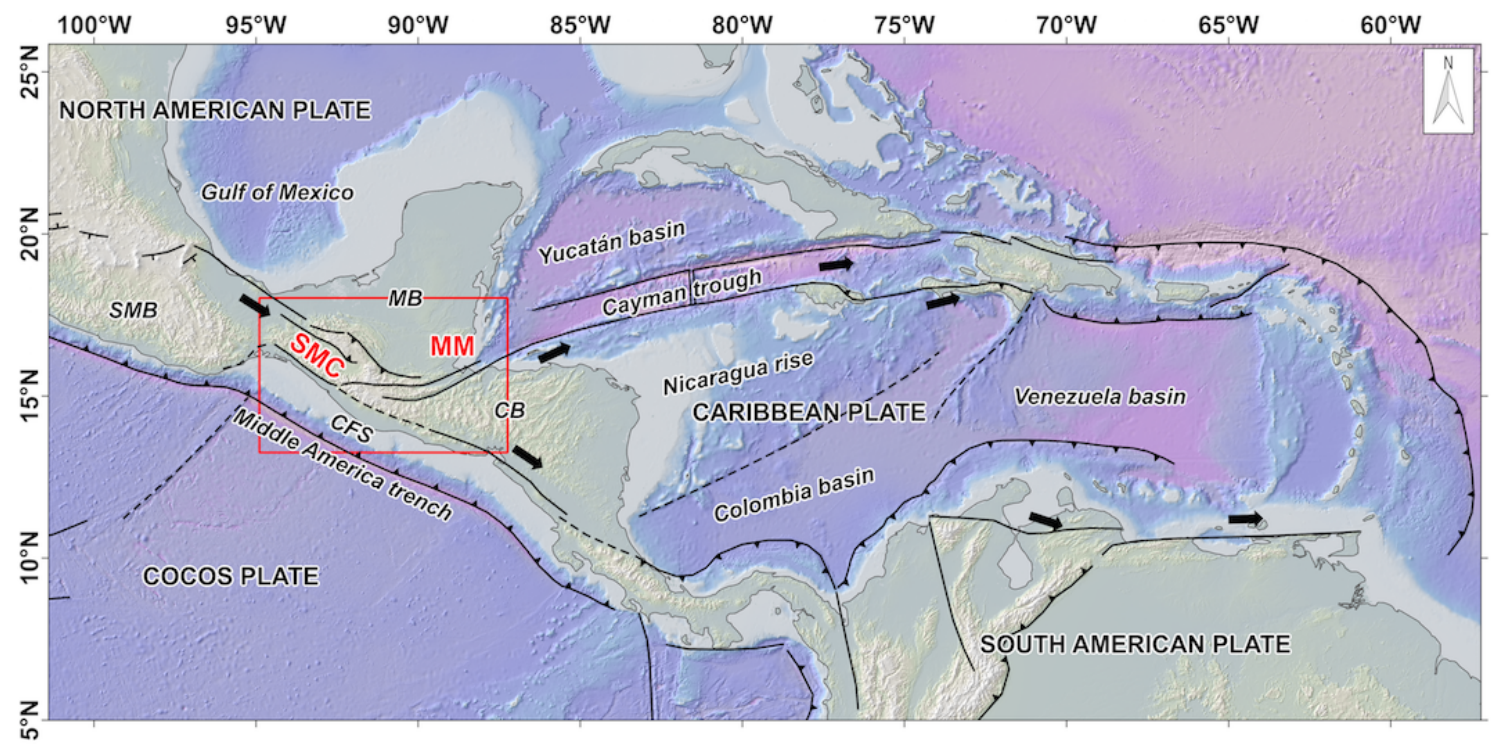

Figure 1. Main plate boundaries in Central America (black lines) and location of the Sierra Madre de Chiapas (SMC) and Maya Mountains $(\mathrm{MM})$ in red. The red box shows the extent of Fig. 2. Abbreviations: CB - Chortis block; CFS - Central America forearc sliver; MB Maya block; SMB - southern Mexico block. Topography and bathymetry from the General Bathymetric Chart of the Oceans (GEBCO, http://www.gebco.net/).

The complexity of the plate boundary comes from the fact that both the Caribbean and the North American Plate are limited to the west by a forearc sliver (Fig. 1) which is coupled to the Cocos slab (e.g., Turner et al., 2007; PhippsMorgan et al., 2008). This sliver rotates counterclockwise as it is pulled by the eastward escape of the Caribbean Plate (e.g., Andreani et al., 2008a; Authemayou et al., 2011). Over the past decades, numerous models regarding the structure and the evolution of the triple junction have been proposed (Authemayou et al., 2011, and references therein). Recent models agree on the fact that the dextral Jalpatagua Fault (Fig. 2) coupled with extension along the grabens of Guatemala represents the limit between the forearc sliver and the Caribbean Plate (e.g., Lyon-Caen et al., 2006; Andreani et al., 2008a; Authemayou et al., 2011; Franco et al., 2012). However, there is no clear consensus on the boundary between the forearc sliver and the North American Plate. This is due to the fact that this boundary is highly diffuse and most of the active deformation is distributed over the Sierra Madre de Chiapas orogenic belt. On top of that, none of the revisited tectonic models of the North American-Caribbean-Cocos plate boundary have attempted to include the Maya Mountains (Figs. 1 and 2). In spite of evidence for recent (late Neogene or Pliocene) tectonics (e.g., Weidie, 1985; Lara, 1993; Purdy et al., 2003; Bauer-Gottwein et al., 2011), this region has been seldom studied due to a dense vegetation cover and scarce roads.

Using geomorphic indices, we attempt to understand the link between tectonics and landscape evolution within these two regions. We discuss the potential effects of varying up- lift, climatic regimes and lithology on geomorphic markers. In active orogens, landscapes result from a competition between vertical uplift, which modifies the base level of rivers, and erosional processes, which result in the progressive rejuvenation of topographic features through time (e.g., Mather, 2000; Snyder et al., 2000). Geomorphic indices are commonly used to detect the response of landscapes to recent deformation processes (Burbank and Anderson, 2001; Keller and Pinter, 1996, and references therein) and several algorithms and toolboxes allow their extraction from digital elevation models (e.g., Schwanghart and Kuhn, 2010; Shahzad and Gloaguen, 2011a). We use topographic profiles and morphometric maps to classify landscapes. The characterization of elevated surfaces allows us to discriminate uplifted relict landscapes and the propagating front of river incision. We also analyze river longitudinal profiles in order to estimate base-level changes which affect the drainage network. Finally, we combine the results from the geomorphic analyses with available geophysical data (GPS and seismicity, Fig. 3) in order to propose a model for the North AmericanCaribbean-Cocos triple junction.

\section{Tectonic setting}

\subsection{Models of the triple junction}

Early geodynamic models of the junction between the North American, Caribbean and Cocos plates consisted of a simple transform-trench boundary. For instance, Burkart (1983) proposed a model in which the Polochic Fault (and perhaps also the Motagua Fault) connected to the Middle America 

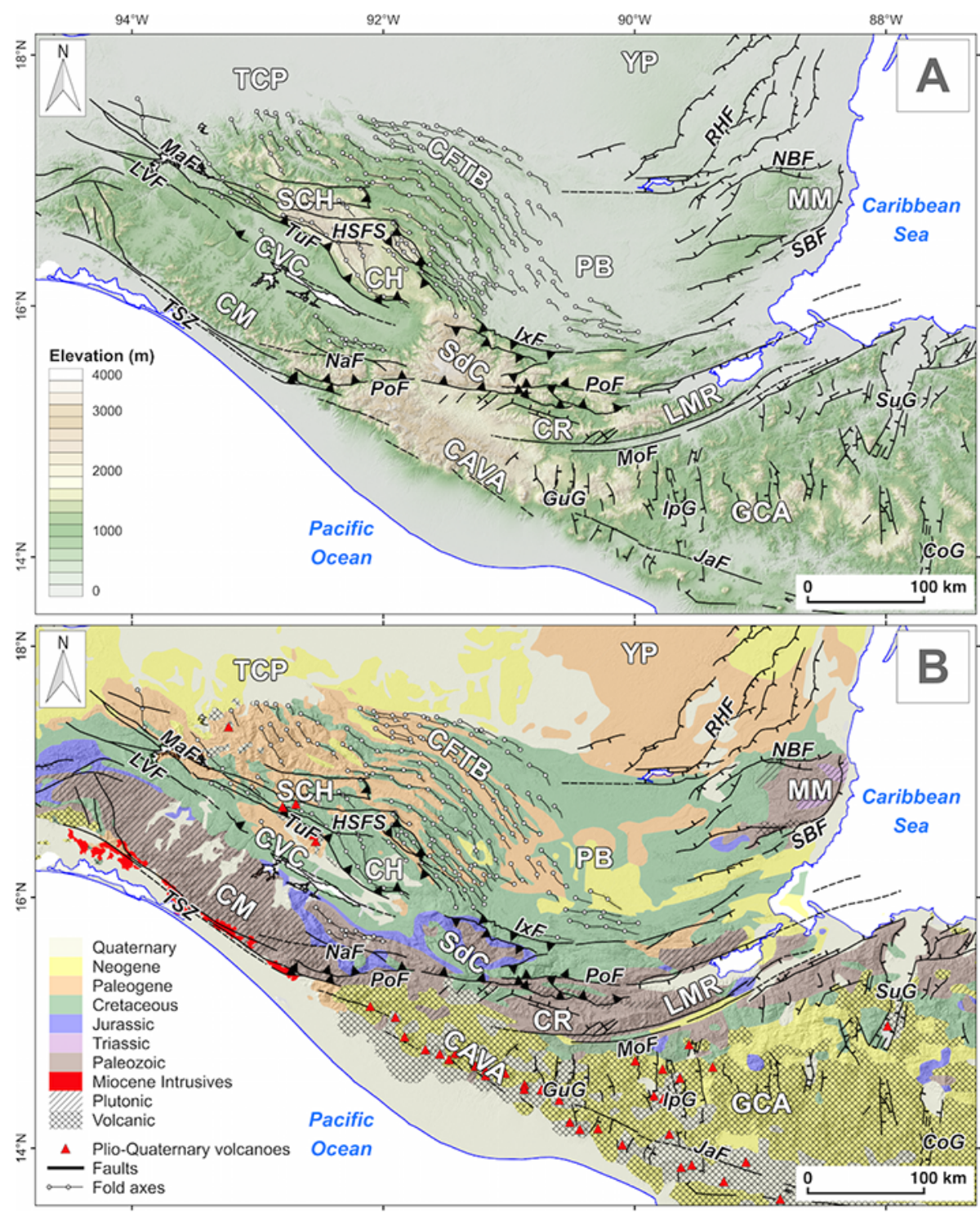

Figure 2. Topography (a) and simplified geological map (b) for northern Central America. Geological contours from Garrity and Soller (2009). Structures compiled from Guzmán-Speziale (2001), Meneses-Rocha (2001), Rogers et al. (2002), Purdy et al. (2003), Ratschbacher et al. (2009), Authemayou et al. (2011) and Witt et al. (2012b). Morpho-tectonic domains: CAVA - Central American volcanic arc; CFTB - Chiapas fold-and-thrust belt; CH - Comitán High; CM - Chiapas Massif; CR - Chuacus range; CVC - Central Valley of Chiapas, EYFZ - eastern Yucatán fault zone; GCA - grabens of Central America; LMR - Las Minas range; MM - Maya Mountains; PB - Petén Basin; SCH - Sierra de Chiapas; SdC - Sierra de los Cuchumatanes; TCP - Tabasco coastal plain; YP - Yucatán platform. Main structures: CoF - Concordia Fault; CoG - Comayagua graben; GuG - Guatemala City graben; HSFS - High Sierra fault system; IpG - Ipala graben; IxF Ixcán Fault; JaF - Jalpatagua Fault; LVF - La Venta Fault; MaF - Malpaso Fault; MoF - Motagua Fault; NaF - Necta Fault; NBF - northern boundary fault; PoF - Polochic Fault; RHF - Rio Hondo Fault; SBF - southern boundary fault; SuG - Sula graben; TSZ - Tonalá shear zone; TuF - Tuxtla Fault.

Trench. He proposed that the $300 \mathrm{~km}$ Neogene motion between the North American and Caribbean plates was accommodated by left-lateral slip along the Polochic and Motagua faults and by extension within the depressions of Honduras and Guatemala. The slip between these two plates was compensated for by a left-lateral offset of the trench.
Later works challenged the idea of a junction between the Polochic-Motagua fault system and the trench because the Polochic fault trace terminates within the Chiapas Massif and the Motagua fault trace is lost within the Central American volcanic arc (e.g., Guzmán-Speziale et al., 1989; GuzmánSpeziale and Meneses-Rocha, 2000). As a result, more recent models (Fig. 4) argue that the motion between the North 

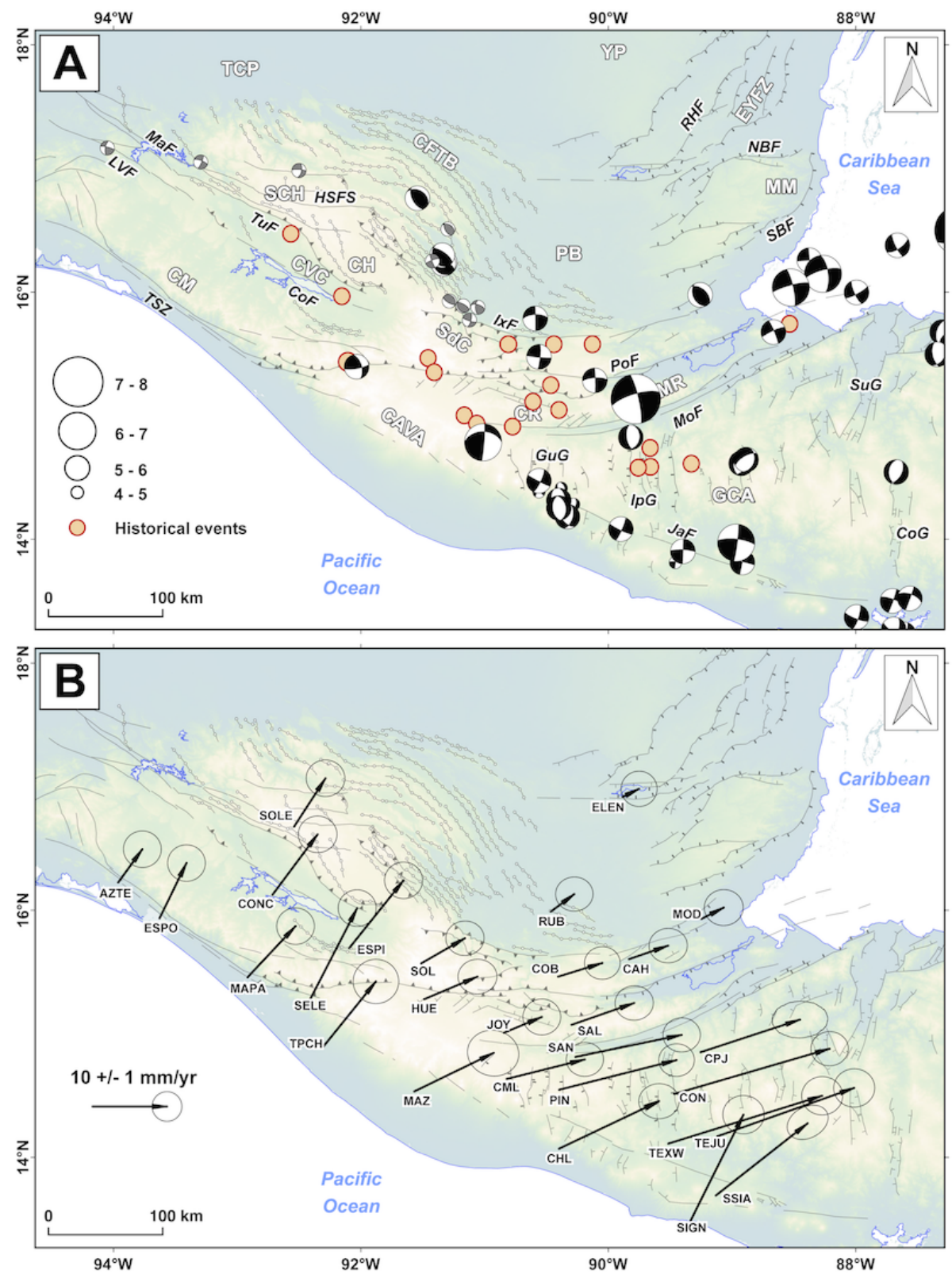

Figure 3. Superficial (depth $<40 \mathrm{~km}$ ) seismicity in northern Central America (a) and GPS velocities with respect to the fixed North American Plate (b). Focal mechanisms from Guzmán-Speziale et al. (1989), Guzmán-Speziale (2010) (in greys) and Global CMT Catalog (in black, http://www.globalcmt.org). Historical earthquakes (red circles) from White (1984), Singh et al. (1984) and Guzmán-Speziale (2010). GPS velocities are from Franco et al. (2012). See Fig. 2 for abbreviations.

American and Caribbean plates does not result in an offset of the trench but is rather absorbed onshore within a complex zone of deformation. However, there is no clear consensus on the geometry of the plate boundary and on how the deformation is distributed inland.

Using seismotectonic data (Fig. 3a), Guzmán-Speziale and Meneses-Rocha (2000) proposed a model in which the Polochic-Motagua fault system is unable to propagate across the Chiapas Massif (Fig. 4a). As a result, a part of the motion between the North American and Caribbean plates is absorbed by the reverse and strike-slip faults of Chiapas (Fig. 4a). In this model, the reverse faults act as a restraining bend between the strike-slip faults and the PolochicMotagua fault system. Later on, Guzmán-Speziale (2001) suggested that part of the plate motion is also absorbed by the grabens of Central America, south of the Motagua Fault (Fig. 4a).

A second category of models (Fig. 4b) mainly focused on the extensional province located south of the Motagua Fault. Gordon and Muehlberger (1994) proposed a model in which 


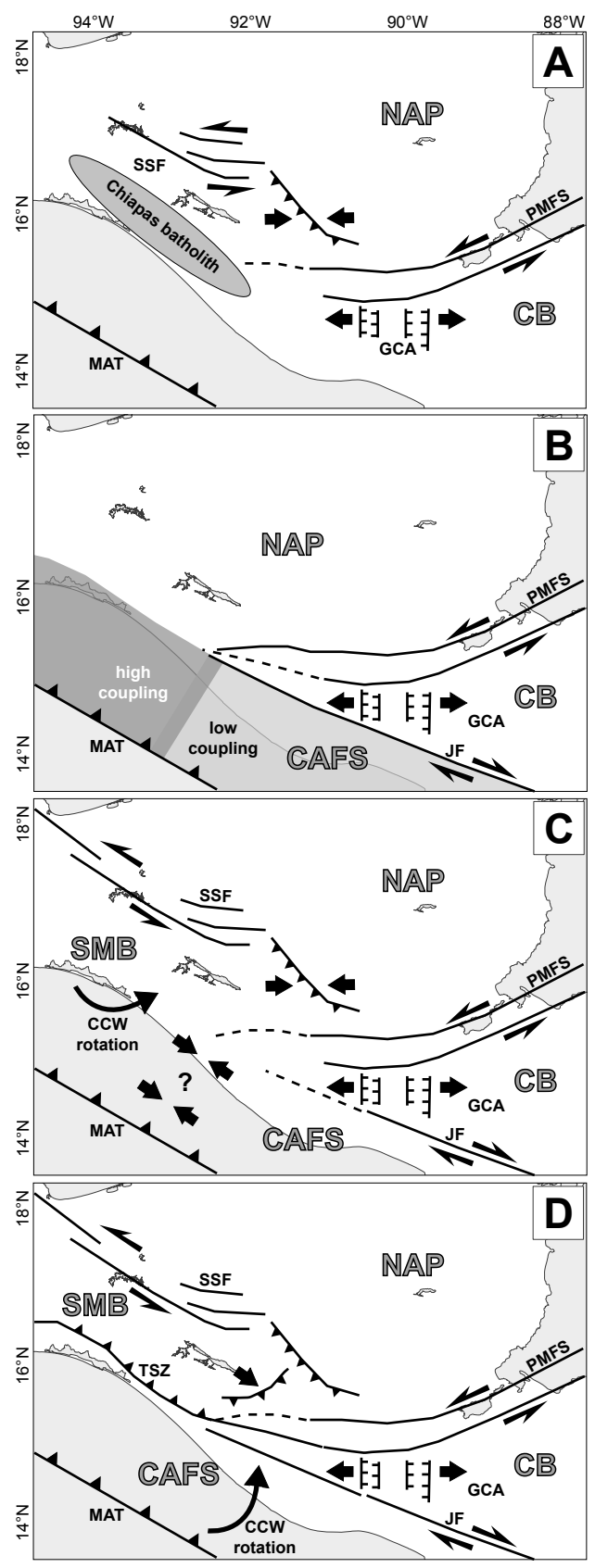

Figure 4. Recent models for the North American-CaribbeanCocos plate boundary in northern Central America. (a) "Faultjog” model from Guzmán-Speziale and Meneses-Rocha (2000) and Guzmán-Speziale (2001). (b) Model from Lyon-Caen et al. (2006) and Franco et al. (2012). (c) Model from Andreani et al. (2008a). (d) "Zipper" model from Authemayou et al. (2011). Main plates and blocks: CAFS - Central America forearc sliver; CB - Chortis block (part of the Caribbean Plate); NAP - North American Plate; SMB - southern Mexico block. Main structures: JF - Jalpatagua Fault; GCA - grabens of Central America; MAT - Middle America Trench; PMFS - Polochic-Motagua fault system; SSF - strike-slip faults of Chiapas; TSZ - Tonalá shear zone. the Chortis block is stretched and rotating counterclockwise along the dextral Jalpatagua Fault, which affects the volcanic arc (Fig. 2), and the Guayape Fault in Honduras. However, more recent works suggest that dextral slip along the Central American volcanic arc is in fact related to a slip partitioning along the trench (e.g., DeMets, 2001; Turner et al., 2007; Correa-Mora et al., 2009). Using GPS data (Fig. 3b), LyonCaen et al. (2006) proposed a model of the plate boundary which took into account both the extensional province and the forearc sliver. They suggested that the eastward escape of the Caribbean Plate was accommodated by dextral slip along the Jalpatagua Fault, by sinistral slip along the PolochicMotagua fault system and by extension within the grabens of Central America (Fig. 4b). This model was refined by Franco et al. (2012), who proposed a difference in coupling along the subduction interface (Fig. 4b) in order to explain the GPS velocity field in southern Mexico (Fig. 3b). However, these two models did not addressed the tectonic evolution of the Sierra Madre de Chiapas.

The most recent models (Fig. 4c and d) have attempted to explain both the eastward escape of the Caribbean Plate as described by Lyon-Caen et al. (2006) and tectonics of the Sierra Madre de Chiapas. Andreani et al. (2008b) suggested a connection between the strike-slip faults of Chiapas; the Veracruz shear zone, which affects the Veracruz Basin further north; and the transtension of the Mexican volcanic arc (Fig. 4c). They proposed that these three zones represent the boundary of the so-called "southern Mexico block" Andreani et al. (2008a). In their model (Fig. 4c), the dynamic of the plate boundary is driven by the escape of the Caribbean Plate and by the counterclockwise rotation of the southern Mexico block. However, this model does not solve the interactions between the southern Mexico block and the Central America forearc sliver. An alternative model was proposed by Authemayou et al. (2011), in which the Central America forearc sliver extends offshore southern Mexico (Fig. 4d). In their model, the eastward escape of the Caribbean Plate induces a counterclockwise rotation of the forearc sliver and a "zipper" process (i.e., progressive suturing) between the Jalpatagua and Motagua faults as the space between the two faults is left "empty" by the moving Caribbean Plate. According to their model, the Tonalá shear zone is a suture resulting from this "zipper" process. However, both the Motagua and Jalpatagua fault traces are lost west of $91^{\circ} \mathrm{W}$. The western termination of both faults seems to be associated with extension along the Guatemala City graben (Lyon-Caen et al., 2006). Furthermore, the Tonala shear zone clearly connects to the Polochic Fault (Fig. 2; Guzmán-Speziale et al., 1989; Guzmán-Speziale and Meneses-Rocha, 2000).

In summary, current views on the plate boundary agree on the fact that the North American and Caribbean plates are limited by a forearc sliver to the west. The counterclockwise rotation of the forearc sliver results in transpression north of the Polochic-Motagua fault system, while the eastward escape of the Caribbean Plate is accommodated by 
the strike slip motions of the Motagua and Jalpatagua faults and by extension along the grabens of Ipala and Guatemala City. However, the connections between the western corner of the Caribbean Plate and the transpressional tectonics of the Sierra Madre de Chiapas are still unclear. In addition, none of these recent models attempted to integrate the recent tectonics of the Maya Mountains and Yucatán Peninsula into the dynamics of the plate boundary.

\subsection{North American-Caribbean plate boundary}

The present-day North American-Caribbean plate boundary consists of three main sinistral faults which delimitate two crustal-scale slivers: the Motagua (Malfait and Dinkelman, 1972; Plafker, 1976), Polochic (Burkart, 1978; Deaton and Burkart, 1984; Sánchez-Barreda, 1981) and Ixcán (GuzmánSpeziale, 2010) faults (Fig. 2). These faults are seismically active (Fig. 3a; White, 1984; Singh et al., 1984; Ambraseys and Adams, 1996; Guzmán-Speziale, 2010) and Quaternary displacements are documented (e.g., Burkart, 1978, 1983; Authemayou et al., 2012). Brocard et al. (2011) described a relict middle Miocene planation surface which formed at low elevation and covered most of the Polochic-Motagua sliver (the so-called "Mayan paleosurface"). This surface was subsequently uplifted and deformed. Using this surface as a marker, Authemayou et al. (2011) estimated the crustal shortening between 17 and $35 \mathrm{~km}$ along the western segment of the Polochic Fault (Fig. 2), where the 13-7 Myr old Mayan paleosurface rests on top of the Sierra de los Cuchumatanes at a maximum elevation of $3800 \mathrm{~m}$.

A part of the motion between the North American and the Caribbean Plate is also accommodated along at least 13 N-trending grabens (e.g., Mann and Burke, 1984; GuzmánSpeziale, 2001) located south of the Motagua Fault. The main structures form the Guatemala City, Ipala, Esquipulas, Sula and Comayagua depressions (Fig. 2). Rogers et al. (2002) related these grabens to the uplift of the Central American Plateau following a slab break-off underneath Central America. The onset of extension has been determined at 11-8 Ma (Gordon and Muehlberger, 1994; Ratschbacher et al., 2009). However, most of the presentday extension (11-12 $\mathrm{mm} \mathrm{yr}^{-1}$ ) seems to be accommodated along the westernmost grabens (Lyon-Caen et al., 2006; Rodriguez et al., 2009; Franco et al., 2012).

\subsection{Sierra Madre de Chiapas}

The Sierra Madre de Chiapas is constituted by four main structural domains: the Chiapas Massif, the Central Valley, the Sierra de Chiapas and the frontal fold-and-thrust belt (Guzmán-Speziale and Meneses-Rocha, 2000; Andreani et al., 2008a; Witt et al., 2012b). The Chiapas Massif mostly consists of Permian igneous rocks affected by medium- to high-grade metamorphism and middle to late Miocene intrusions related to the subduction of the Cocos Plate (Damon and Montesinos, 1978; Weber et al., 2007; Molina-Garza et al., 2015). The western flank of the Chiapas Massif is bounded by the left-lateral Tonalá shear zone, which connects to the south to the western termination of the Polochic Fault (Wawrzyniec et al., 2005; Weber et al., 2005). The displacement along the Tonalá shear zone is synchronous with Miocene magmatic intrusions and could have reached $100 \mathrm{~km}$ (Molina-Garza et al., 2015). The Central Valley is a $\sim 170 \mathrm{~km}$ long and $\sim 30 \mathrm{~km}$ wide depression corresponding to a NW-trending synclinorium with superimposed smaller folds (Witt et al., 2012b). The Sierra de Chiapas has a roughly sigmoidal shape and is bounded to the west by the prominent NW-trending left-lateral Tuxtla Fault. It is constituted by blocks culminating at heights between 2000 and $2400 \mathrm{~m}$ and delimited by E-trending left-lateral faults defined as the High Sierra fault system by Witt et al. (2012b). These faults probably connect to the Malpaso Fault to the west, while strike-slip motion is absorbed at their eastern terminations by thrusting and folding. The Chiapas frontal fold-and-thrust belt is located between the Sierra de Chiapas and the western border of the Yucatán platform. It is constituted by closely spaced faulted folds which are rooted in shallow levels (Witt et al., 2012b).

Thermochronological, tectonic and stratigraphic evidence suggests that renewed exhumation and topographic growth occurred along the Chiapas region during the middle Miocene (16-10 Ma) and late Miocene-Pliocene (6-5 Ma), following a phase of rapid exhumation to upper crustal levels at $\sim 30 \mathrm{Ma}$ (Ratschbacher et al., 2009; Witt et al., 2012a). The Tonalá shear zone may have accommodated significant deformation since $16 \mathrm{Ma}$, while the displacement along the transpressive Tuxtla and Malpaso faults occurred during the last 6-5 Myr and could have reached $50-70 \mathrm{~km}$, involving $0.5-0.8 \mathrm{~cm} \mathrm{yr}^{-1}$ of left-lateral motion (Meneses-Rocha, 2001; Witt et al., 2012b).

\subsection{Maya Mountains and Belize margin}

The Maya Mountains and the Belize margin are located north to the Polochic-Motagua fault system and east to the Yucatán platform. Due to a dense vegetation cover and scarce roads, this region has been seldom studied in comparison with other areas related to the North American-Caribbean plate boundary.

The eastern border of the Yucatán Peninsula is crosscut by a series of NNE-trending normal faults (e.g., Weidie, 1982, 1985), which are referred to as eastern Yucatán fault zone (EYFZ) in Fig. 2. The fault zone is $\sim 80 \mathrm{~km}$ wide and extends over $500 \mathrm{~km}$ between the NE tip of the Yucatán Peninsula and the Maya Mountains. The surface expression of this fault zone is seen in the alignment of topographic scarps, hydrological features (cenotes, lakes and rivers) and coastal bays (Weidie, 1985; Lesser and Weidie, 1988; Bauer-Gottwein et al., 2011). The eastern Yucatán fault zone represents the onshore continuation of an extensive horst and graben sys- 
tem which affects the western margin of the Yucatán Basin (Weidie, 1985; Rosencrantz, 1990).

According to Rao and Ramanathan (1988) and Purdy et al. (2003), the Maya Mountains correspond to a roughly NE-trending structural high where the Paleozoic basement is uplifted. Paleozoic rocks constitute the highest elevations of the Maya Mountains. The orogen mainly consists of metamorphosed late Carboniferous to middle Permian volcano-sedimentary rocks overlying late Silurian granites and is bounded by the northern and southern boundary faults (Kesler et al., 1974; Bateson and Hall, 1977; Steiner and Walker, 1996). The Maya Mountains are delimited by faultbounded E- to NE-trending depressions: the Corozal Basin located to the north and the Belize Basin that borders the Maya block offshore to the east and onshore to the south. According to Purdy et al. (2003), unroofing of the Cretaceous carbonate cap of the Maya Mountains siliciclastic sediment source did not occur until late Neogene, perhaps no earlier than late Pliocene. Faulting along the Belize margin is not accurately documented. The most recent tectonic event is Pliocene or younger and the resulting structures affected Quaternary carbonate deposition. However, Lara (1993) related this event to transtensional faulting, while Purdy et al. (2003) instead interpreted this event as the result of a transpression.

\section{Geomorphic analyses: methods and tools}

\subsection{Swath topographic profiles}

Swath topographic profiles condense elevation data of a complex region into a single profile (e.g., Isacks, 1992; Masek et al., 1994; Telbisz et al., 2013; Hergarten et al., 2014). Topography is extracted from a rectangular swath using a series of parallel profiles, rather than using a single line as in conventional topographic profiles. Elevation data are then projected onto a vertical plane parallel to the longitudinal axis of the swath rectangle, and statistical parameters (the maximum, minimum and mean elevations) are calculated. The curve for maximum elevation corresponds to the ridgelines and helps to identify topographic features, such as relicts of paleosurfaces. The curve for minimum elevation corresponds to the valley floors or river beds. A quick estimate of the incision is given by the arithmetic difference between the maximum and minimum elevations in a given longitudinal distance (window).

Swath topographic profiles were extracted from 3 arcsec SRTM data from CIAT (Jarvis et al., 2008) using a MATLAB script. The swath width was fixed to $20 \mathrm{~km}$. This width is large enough to contain both elevated surfaces and major rivers and small enough to avoid topographic features that are too oblique with respect to the swath axis. Elevation data were sampled using $\sim 220$ parallel profiles separated by $90 \mathrm{~m}$. Elevations along each individual profile were also sampled using a 1-pixel $(90 \mathrm{~m})$ interval.

\subsection{Surface analyses}

The combined use of different morphometric indices proves to be an efficient way to classify landscapes according to their state of dynamic equilibrium (e.g., Andreani et al., 2014; Domínguez-González et al., 2015). Hypsometric integral (HI) efficiently highlights topographic scarps, surface roughness (SR) substantially increases with incision and relief anomaly (RA) and surface index (SI) highlights elevated low-relief landscapes.

The HI shows the distribution of landmass volume remaining beneath or above a basal reference plane (Strahler, 1952; Schumm, 1956). This index proved to be efficient in evaluating the response of landscapes to active tectonics (e.g., Pérez-Peña et al., 2009; Mahmood and Gloaguen, 2012; Siddiqui and Soldati, 2014; Andreani et al., 2014; DomínguezGonzález et al., 2015). According to Pike and Wilson (1971), the HI for a given area can be approximated with Eq. (1):

$\mathrm{HI}=\frac{h_{\text {mean }}-h_{\text {min }}}{h_{\max }-h_{\min }}$,

with $h_{\text {mean }}, h_{\text {min }}$ and $h_{\text {max }}$ being the mean, minimum and maximum elevations of the analyzed area.

Surface roughness can be described by several parameters (Smith, 2014, and references therein). In this work we used the area ratio approach, which evaluates the similarities between a topographic surface with a given area and a flat surface with the same geographic extent (e.g., Hobson, 1972; Grohmann, 2004; Grohmann et al., 2009; Shahzad and Gloaguen, 2011b). The ratio is close to 1 for flat areas and increases rapidly as the real surface becomes irregular. The method used to obtain the "real" and flat surfaces is adapted from the GRASS-R algorithm of Grohmann (2004). First, a slope map is produced using the neighborhood algorithm included in ArcGIS (Burrough and Mcdonell, 1998). The "real" surface $S_{\mathrm{R}}$ is then obtained for each pixel using Eq. (2):

$S_{\mathrm{R}}=\operatorname{res} \times \sqrt{\operatorname{res}^{2}+\left(\tan (\alpha) \times \operatorname{res}^{2}\right.}$,

where "res" is the DEM resolution in meters and $\alpha$ is the pixel slope in degrees. The flat area $S_{\mathrm{F}}$ is defined for each pixel by $S_{\mathrm{F}}=$ res $\times$ res. The surface roughness is then obtained by summing the pixel values of $S_{\mathrm{R}}$ and $S_{\mathrm{F}}$ within a moving window and by dividing the sum of $S_{\mathrm{R}}$ pixels by the sum of $S_{\mathrm{F}}$ pixels.

We computed the hypsometric integral and surface roughness from $90 \mathrm{~m}$ resolution SRTM data (CIAT; Jarvis et al., 2008) using TecDEM, a MATLAB-based toolbox (Shahzad and Gloaguen, 2011b). Each pixel of the output raster represents the hypsometric integral and surface roughness values for a $15 \times 15 \mathrm{~km}$ moving window. The choice of the window size depends on the objectives. The size of the window will affect the amount of smoothing on the relief (low-pass filtering). To get rid of high-frequency signals such as erosion 
patterns, the window must encompass a sufficient portion of the analyzed landscape and thus be larger than the wavelength of the undesired signal. Otherwise, computed values will reflect local-scale variations in relief such as hillslopes. Smallest window scales, aside from being noisy due to highfrequency signals, can also be more influenced by errors (e.g, Albani et al., 2004; Tarolli et al., 2012; Sofia et al., 2013, 2014). In the present case, a $15 \mathrm{~km}$ window allows for the effect of the drainage system to be filtered out as the window size represents an area that will include several valleys and ridges (Andreani et al., 2014).

Finally, we used the relief anomaly (Scotti et al., 2014) and the surface index (Andreani et al., 2014) to highlight elevated and low-relief landscapes. The relief anomaly (RA) represents the elevations normalized by the local relief. We computed this index for a given area using Eq. (3):

$\mathrm{RA}=\frac{h_{\text {mean }}}{h_{\max }-h_{\text {min }}}$,

with $h_{\text {mean }}, h_{\text {min }}$ and $h_{\text {max }}$ being the mean, minimum and maximum elevations of the analyzed area. Highest values are obtained for flat and elevated surfaces.

The surface index (SI) combines the elevations from the DEM with the computed maps of hypsometric integral and surface roughness. It allows for discriminating areas with low local relief landscapes from areas with a more rugged topography. To compute this index, rasters of elevations, hypsometric integral and surface roughness are normalized by their respective minimum and maximum values in order to obtain pixels values between 0 and 1 . We then combine the newly created rasters using Eq. (4):

$\mathrm{SI}=\left(N_{\mathrm{h}} \times N_{\mathrm{HI}}\right)-N_{\mathrm{SR}}$,

with $N_{\mathrm{h}}, N_{\mathrm{HI}}$ and $N_{\mathrm{SR}}$ being the normalized elevations, hypsometric integral and surface roughness values, respectively. Positive surface index values correspond to elevated surfaces with low local relief while negative values highlight rugged landscapes.

\subsection{Modeling of the drainage network}

We extracted the drainage network from $30 \mathrm{~m}$ resolution SRTM data. The extraction was done using TecDEM (Shahzad and Gloaguen, 2011a) by calculating flow directions and contributing area for each pixels using the D8 algorithm (O'Callaghan and Mark, 1984; Fairfield and Leymarie, 1991; Jones, 2002). Streams were identified using a minimum contributing area of $1 \mathrm{~km}^{2}$. This threshold is introduced in order to take into account the transition from colluvial to stream-flow- (fluvial) dominated channel, which is usually observed at $\sim 1 \mathrm{~km}^{2}$ in temperate humid regions (e.g., Montgomery and Foufoula-Georgiou, 1993; Wobus et al., 2006). It is assumed that a theoretical flow accumulation that drains an area larger than $1 \mathrm{~km}^{2}$ can be associated with a real water channel. Extracted streams were then organized hierarchically using Strahler (1957) order.

A DEM-based procedure allows for a regional-scale drainage network to be easily extracted and analyzed. However, there are several uncertainties related to the DEM and methods. Extracted drainage network and contributing areas are affected by the quality and sampling of the DEM. Free and commonly used data include the $1 \operatorname{arcsec}(\mathrm{ca} .30 \mathrm{~m})$ and the $3 \operatorname{arcsec}(\mathrm{ca} .90 \mathrm{~m}$ ) resolution SRTM. For both data sets the absolute vertical error is reported to be less than $20 \mathrm{~m}$. In some areas, the available 1 arcsec SRTM data presented voids (i.e., pixels with no data) mainly located in ridges. We filled these voids with 3 arcsec SRTM data.

The flow-routing method we use (D8 algorithm) may introduce bias in flow path orientation as it discomposes flow directions into units of $45^{\circ}$ (Fairfield and Leymarie, 1991). This is especially the case in flat areas. Additional known bias are related to methodological aspects. In our study area the commonly encountered problem concerned nested depressions which are related to DEM imperfections. These pits need to be filled to create flow directions. Other artifacts are mainly found along entrenched rivers and canyons, where bad pixel values "block" the path of the extracted rivers. In two cases (Sumidero and La Venta canyons) the DEM filling resulted is a significant deviation of the modeled rivers with respect to the actual rivers. We thus manually carved the DEM (i.e., we decreased the elevation of the bad pixels blocking these two canyons) in order to obtain a more accurate flow path. The original topography is also affected by human artifacts such as dammed rivers. This is especially the case for the Grijalva River in southern Mexico. Artificial flats related to DEM filling or dammed rivers introduce errors in extracted river paths. These errors are easily detected in river longitudinal profiles and were taken into account when interpreting the knickzones in extracted rivers.

\subsection{Analysis of river longitudinal profiles}

Deviations from the typical concave-up shape of stream longitudinal profiles, such as knickpoints or convex segments, indicate a disequilibrium state resulting from tectonic, base level or lithological perturbations (Kirby and Whipple, 2001; Chen et al., 2003; Troiani and Della Seta, 2008; Pedrera et al., 2009; Font et al., 2010). The normalized steepness in$\operatorname{dex}\left(k_{\mathrm{sn}}\right)$ is widely used to investigate tectonically induced perturbations in river longitudinal profiles and has been used to propose patterns of uplift (Kirby and Whipple, 2001; Wobus et al., 2006; Whittaker et al., 2008). The relationships between slope and catchment area which define the equilibrium state channel gradient are given by Eqs. (5) and (6) (Flint, 1974; Kirby and Whipple, 2001; Wobus et al., 2006):

$S=k_{\mathrm{S}} \times A^{-\theta}$ 
with

$k_{\mathrm{s}}=\left(\frac{U}{K}\right)^{\frac{1}{n}}$

where $S$ is the local channel slope, $\theta$ is the channel concavity, $k_{\mathrm{S}}$ is the steepness index, $A$ is the upstream drainage area, $U$ is the rock uplift rate and $K$ is the dimensional coefficient of erosion. As suggested by Wobus et al. (2006, and the references therein) a normalized steepness index $k_{\mathrm{sn}}$ is used, since $k_{\mathrm{s}}$ and $\theta$ are strongly correlated.

In some cases, the upstream portions located above prominent knickpoints are associated with an upper-relict landscape. Landscapes tend towards an equilibrium in which rivers are graded to sea level or local base level. Tectonic or climatically induced base-level falls modify the equilibrium of the drainage. The result is an erosion wave propagating upstream and the areas not yet affected by the erosion wave form an upper-relict landscape (e.g., Clark et al., 2005; Reinhardt et al., 2007; Pérez-Peña et al., 2015). The reconstruction of the original stream profile downstream of the convexity provides an estimate for the amount of base-level change and subsequent incision (Schoenbohm et al., 2004; Clark et al., 2005; Gallen et al., 2013). To reconstruct the original stream profile, we used the power law between slope and distance defined by Eq. 7 (Hack, 1957):

$S=i \times D^{j}$

$S$ is the local channel slope and $D$ is the distance from the drainage divide. Parameters $i$ and $j$ are obtained by regressing the upper segment of the stream profile in a logarithmic plot of slope against distance.

We analyzed river longitudinal profiles using TecDEM (Shahzad and Gloaguen, 2011a). Normalized steepness indices were computed from Eq. (5) using regressions of slope versus catchment area in logarithmic plots with a given reference concavity $\theta_{\text {ref }}=0.45$ (Kirby and Whipple, 2001; Wobus et al., 2006). Prominent knickpoints or convex anomalies can be observed directly on river longitudinal profiles. However, logarithmic plots of slope against catchment area allow a more detailed analysis, as minor anomalies in the gradient of rivers can be easily detected. For each longitudinal profile, we selected and regressed several segments delimited by changes in the gradient of the river. We then plotted regressed segments and their assigned $k_{\mathrm{sn}}$ values on a map. The reconstruction of stream profiles was done by regressing the segments located upstream of knickzones in logarithmic plots of the slope against the distance (Eq. 7). We used a MATLAB-based script implemented in TecDEM by Andreani et al. (2014).

The integer format of DEMs locally produces multiple flats with zero slope, which cannot be handled in logarithmic plots (e.g., Kirby and Whipple, 2001; Wobus et al., 2006). This issue is commonly solved by smoothing extracted river profiles (Wobus et al., 2006). However, this may induce bias in extracted geomorphic indices, especially for segments located close to major knickpoints. In this study we smoothed extracted river profiles using a 20-pixel (ca. $600 \mathrm{~m}$ ) moving window. We used a bootstrapping approach in order to address uncertainties related to both DEM artifacts and methods (Andreani et al., 2014). Linear regressions used to compute both normalized steepness indices and reconstruction of stream profiles are based on subsamples. Typically, from logarithmic plots we randomly selected $75 \%$ of the points corresponding to the analyzed segment in order to obtain 500 subsets. We then performed a regression on each subset. We obtain the mean values as well as a range for both normalized steepness indices and reconstructed profiles.

\subsection{Isobase maps from rivers}

The spatial distribution of stream height (isobase map) is a useful proxy for investigating geologic or tectonic processes (e.g., Dury, 1952; Filosofov, 1960; Golts and Rosenthal, 1993; Grohmann et al., 2007, 2011). Drainage networks are commonly organized according to Strahler (1957) stream order. According to Golts and Rosenthal (1993) streams of similar orders are of similar geological age and are related to similar geological events. Hence the interpolation of isobase lines, which connect streams with a similar order, produce a surface resulting from the same erosional events. As suggested by Grohmann et al. (2011), isobase maps can be seen as a smoothed version of the original topographic surface, from which was removed the "noise" of the first Strahler order stream erosion. Sharp topographic changes affecting an isobase surface were used to infer potential structures or uplifted blocks associated with tectonic movements (e.g., Golts and Rosenthal, 1993; Grohmann et al., 2007; DomínguezGonzález et al., 2015).

Isobase maps were computed using the drainage network extracted from the $30 \mathrm{~m}$ resolution SRTM data (see Sect. 3.3). Using SAGA GIS software we selected streams with a Strahler order $\geq 2$ and we interpolated the elevations from extracted rivers using a natural neighbor method.

\section{Results}

\subsection{Swath topographic profiles}

We analyzed the topography of the Sierra Madre de Chiapas and Maya Mountains along five swath profiles (location in Fig. 5a). For each profile (Fig. 6) we extracted the minimum, mean and maximum elevation along the swath. We estimated the local incision by subtracting the maximum and minimum elevation. We also plotted the annual averaged precipitation derived from the Tropical Rainfall Measuring Mission (TRMM, Fig. 5b). Processed TRMM data for the 19982009 period are provided by Bookhagen (2009). Swath profiles 1-3 (Fig. 6) are perpendicular to major mountain belts and faults in the Sierra Madre de Chiapas. The fourth one 


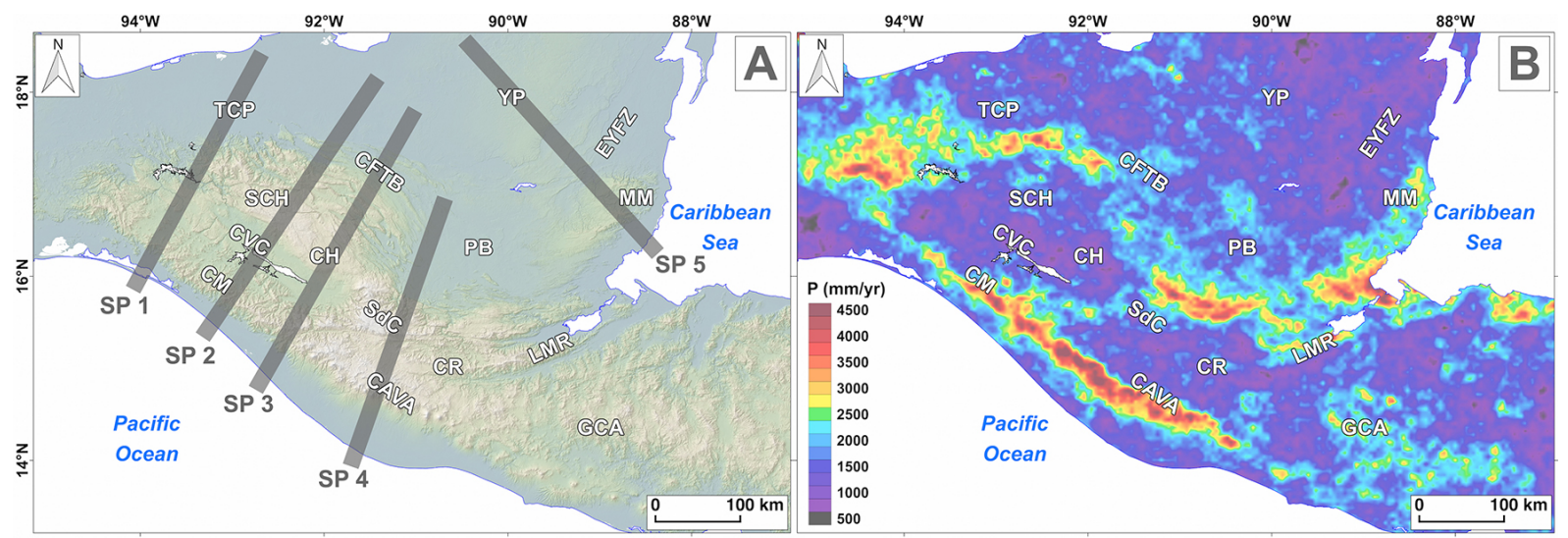

Figure 5. Location of swath topographic profiles (a) and annual averaged precipitation derived from the Tropical Rainfall Measuring Mission (TRMM) for the 1998 to 2009 period (b). Processed TRMM data are provided by Bookhagen (2009). See Fig. 2 for abbreviations.

(profile 4 in Fig. 6) intersects the volcanic arc, the Sierra de los Cuchumatanes and the Petén Basin. The last profile (Fig. 6) displays main topographic trends across the Maya Mountains and the Yucatán platform.

\subsubsection{Sierra Madre de Chiapas}

The Chiapas Massif (profiles 1-3, Fig. 6) dominates the pacific coastal plain. Its SW boundary is abrupt and corresponds to the linear trace of the Tonalá shear zone. The topography of the Chiapas Massif increases from 1500 to $3000 \mathrm{~m}$ toward the SE. River incision (green curves in Fig. 6) increases significantly southward (from $\sim 700$ to $\sim 1500 \mathrm{~m}$ ). The range appears strongly asymmetric in profiles 1 and 2 . The drainage divide (indicated by a peak in minimum elevations) is located close to the trace of the Tonalá shear zone. The SW flank facing the Pacific coastal plain is steep, while the opposite side of the range is gently dipping towards the NE. The curve for minimum elevations also indicates that rivers flowing towards the inner part of the Sierra Madre de Chiapas have a gentle gradient in comparison with those flowing into the Pacific.

The Central Valley (profiles 2 and 3, Fig. 6) corresponds to a $\sim 40 \mathrm{~km}$ wide depression. Despite a mean elevation of $\sim 600 \mathrm{~m}$ the local incision appears to be less than $100 \mathrm{~m}$. The topographic scarp associated with the Concordia Fault is barely marked. In contrast, the La Venta and Tuxtla faults delimitate a $\sim 1500 \mathrm{~m}$ topographic high (referred to as the "La Venta block", profile 1 in Fig. 6) which acts as a barrier for rivers coming from the Chiapas Massif.

In profile 1, the Tuxtla and Malpaso faults represent the boundary between the La Venta block and the Chiapas foldand-thrust belt. In profiles 2 and 3 the Tuxtla Fault represents the limit between the Central Valley and two topographic highs: the Sierra de Chiapas and the Comitán High. The Sierra de Chiapas forms an impressive bulge which dominates both the Central Valley and the Chiapas fold-and- thrust belt. Its central area is relatively flat and culminates at $\sim 2500 \mathrm{~m}$. The topography of the Comitán High is flat with very low incision by the drainage network and the mean elevation is $\sim 1600 \mathrm{~m}$. This flat surface is limited to the east by a topographic high (referred to as the "Leyva Velázquez block", profile 3 in Fig. 6) which belongs to the Chiapas foldand-thrust belt. While in profile 1 the elevation of the foldand-thrust belt is constant, in profiles 2 and 3 the topography of the belt is asymmetric and elevations gently decrease toward the flat Tabasco coastal plain.

Peaks in precipitation indicate orographic effects along the Pacific side of the Chiapas Massif (profiles 1-3 in Fig. 6) and along the northern part of the Chiapas fold-and-thrust belt (profiles 1 and 2 in Fig. 6). However, the shadowing effect of these ranges appears limited as we observe no significant drop in the amount of precipitation between the inner parts of the Sierra Madre de Chiapas and surrounding areas (Pacific coast and Tabasco coastal plain).

\subsubsection{Volcanic arc and Sierra de los Cuchumatanes}

In profile 4 (Fig. 6) the volcanic arc domain appears as an uplifted plateau with elevations reaching $3500 \mathrm{~m}$. The curve for minimum elevations indicate that the main drainage divide is located close to the NE limit of the volcanic arc. Rivers flowing towards the Pacific deeply incised the volcanic arc as the local incision reaches up to $2500 \mathrm{~m}$. We also observe an orographic effect on precipitation. The region beyond the volcanic arc consists of a relatively flat depression which may in fact represent a back-arc plateau (profile 4 in Fig. 6). The shadowing effect of the surrounding ranges does not result in significantly dryer conditions. Precipitation within the depression range between 1000 and $1500 \mathrm{~mm} \mathrm{yr}^{-1}$, while they range between 1500 and $2000 \mathrm{~mm} \mathrm{yr}^{-1}$ along the $\mathrm{Pa}-$ cific coast and Petén Basin. This area shows a moderate incision by the drainage network in comparison with the volcanic arc and the Sierra de los Cuchumatanes. The curve for min- 

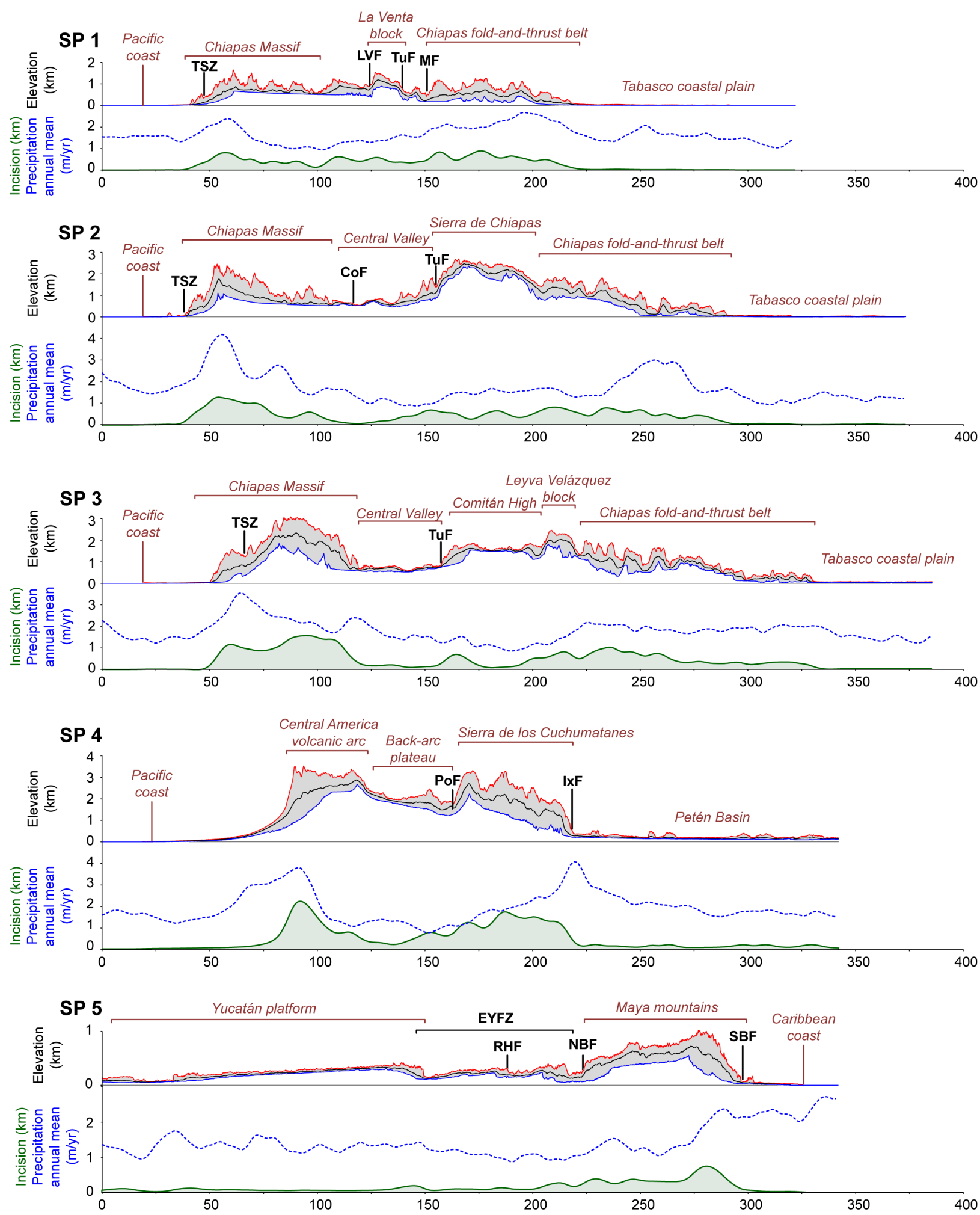

Figure 6. Swath profiles across the Sierra Madre de Chiapas, volcanic arc, and Maya Mountains. Upper plots: topographic profiles (swath width is $20 \mathrm{~km}$ ). Vertical exaggeration is 10 for profiles $1-4$ and 25 for profile 5. Red, black and blue curves represent the maximum, mean and minimum elevations, respectively. Lower plots: green lines represent the local incision in $\mathrm{km}$ (subtraction of minimum and maximum elevations). Blue dashed lines represent annual averaged precipitation (derived from TRMM data) in $\mathrm{m} \mathrm{yr}^{-1}$. See Fig. 2 for abbreviations. 
imum elevations suggests a significant base-level drop between rivers flowing within the inner part of the back-arc plateau and the drainage associated with the Polochic fault trace.

The Sierra de los Cuchumatanes (profile 4 in Fig. 6) is bounded by two impressive scarps associated with the Polochic and Ixcán faults. The Sierra de los Cuchumatanes is also deeply incised, with local incision values up to $1500 \mathrm{~m}$. The general topographic trend of the range, with higher elevations along the Polochic Fault, suggests a tilt towards the NE. The asymmetry of the drainage is possibly related to the tilt of the range or to an orographic effect (or to a combination of both factors). However, the peak in precipitation is located along the Ixcán Fault. In spite of a SW gradient (from 2500 to $1500 \mathrm{~mm} \mathrm{yr}^{-1}$ ), most of the Sierra de los Cuchumatanes receives as much as rain as the Petén Basin $\left(2000 \mathrm{~mm} \mathrm{yr}^{-1}\right)$. Finally, the flat and regular topography of the Petén Basin contrasts with the elevated and incised topography of the others areas.

\subsubsection{Maya Mountains}

In topographic profile (profile 5 in Fig. 6) the Maya Mountains are delimited by two major scarps related to the NEtrending southern boundary fault and the two NE- and E-trending northern boundary faults. The topography of the Maya Mountains is asymmetric and the range appears slightly tilted towards the NW. The main drainage divide, as well as highest elevations (up to $1000 \mathrm{~m}$ ), is located close to the southern boundary fault. As indicated by the curve for local incision (profile 4 in Fig. 6), the areas located east of the main drainage divide are more eroded (up to $750 \mathrm{~m}$ of incision) in comparison with the areas located on the other side of the drainage divide were the main river incised the initial topography by $300-400 \mathrm{~m}$. We also observe a drop in the amount of precipitation (from 2500 to $1500 \mathrm{~mm} \mathrm{yr}^{-1}$ ) along the southern side of the Maya Mountains.

The topography of the Yucatán platform (profile 4 in Fig. 6) appears to be controlled by the NE-trending eastern Yucatán fault zone. The faults are located within a $\sim 80 \mathrm{~km}$ wide corridor and delimitate tilted blocks. Highest elevations and incisions are located close to the fault traces and decrease towards the NW. The inner part of the Yucatán platform (located west of the fault zone) is characterized by a well-defined and continuous surface. This surface is poorly incised (local incision is less than $100 \mathrm{~m}$ ) and appears to be tilted towards the NW.

\subsection{Morphometric maps}

The hypsometric integral values (Fig. 7a) appear to be essentially controlled by tectonic features. Highest values are mainly found along fault-related topographic scarps, while lowest values are located within depressions and flat areas. In the Chiapas region, areas such as the coastal plain, the
Central Valley and the inner part of the Comitán High are associated with low hypsometric integral values $(\mathrm{HI} \leq 0.35)$. These are flat areas as seen in swath topographic profiles. Both the Tonala shear zone and the Tuxtla fault scarps are highlighted by higher values $(\mathrm{HI}>0.35)$. However hypsometric integral values are significantly greater for the Tuxtla fault scarp (HI > 0.55).

The structural control is also obvious in some other regions. The mountain belt north to the Polochic Fault displays rather high hypsometric values. Within the extensional province of Central America, structures such as the Ipala, Comayagua and Sula grabens are associated with hypsometric lows. The pattern of hypsometric values also highlights the N- to NE-trending lineaments of the eastern Yucatán fault zone (e.g., Rio Hondo Fault) which are located along the Belize margin.

The surface roughness map (Fig. 7b) reveals the location of strongly incised areas as well as flat surfaces. Peak values (> 1.07 in Fig. 7b) are essentially found along the central and southern part of the Tonalá shear zone, the NW tip of the Central American volcanic arc, the mountain belt located north to the Polochic Fault (e.g., Sierra de los Cuchumatanes) and Las Minas range (located between the Motagua and Polochic faults). These areas are both elevated (altitudes between 2500 and $4000 \mathrm{~m}$ ) and strongly eroded. As seen in our swath topographic profiles (Fig. 5), the difference in elevation between ridges and valley floors (local incision) is between 1500 and $2500 \mathrm{~m}$. Intermediate surface roughness values (1.03-1.07 in Fig. 7b) are mainly found within the inner part of the Chiapas fold-and-thrust belt, along the eastern part of the Maya Mountains and within the grabens of Central America.

As for hypsometry, the distribution of surface roughness values in the extensional province is structurally controlled. Lowest values highlight graben floors, while highest values correspond to horsts. Lowest surface roughness values $(<1.03$ in Fig. 7b) emphasize flat (i.e., low amplitude) landscapes. Some of these areas (e.g., Central Valley of Chiapas, Comitán High) correspond to elevated surfaces and plateaus observed in swath topographic profiles (Fig. 6).

Surface roughness and hypsometric integral do not allow for discrimination of low-relief landscapes according to their topographic elevations. For this purpose we use two additional geomorphic indices: the relief anomaly (Fig. 8a) and the surface index (Fig. 8b). Both maps give similar results regarding the distribution of elevated and low-relief landscapes, which are identified by the highest relief anomaly values $(>16)$ in Fig. $8 \mathrm{a}$ and by positive $(0-0.5)$ surface index values in Fig. 8b. Within the Sierra Madre de Chiapas, elevated and low-relief landscapes are mainly located within the Central Valley of Chiapas and the areas located east of the Tuxtla Fault (Sierra de Chiapas and Comitán High). The drainage system of the Chiapas Massif (consisting of large and flat valleys) is also highlighted. The two maps also show the extent of the elevated plateaus located at the northern tip 

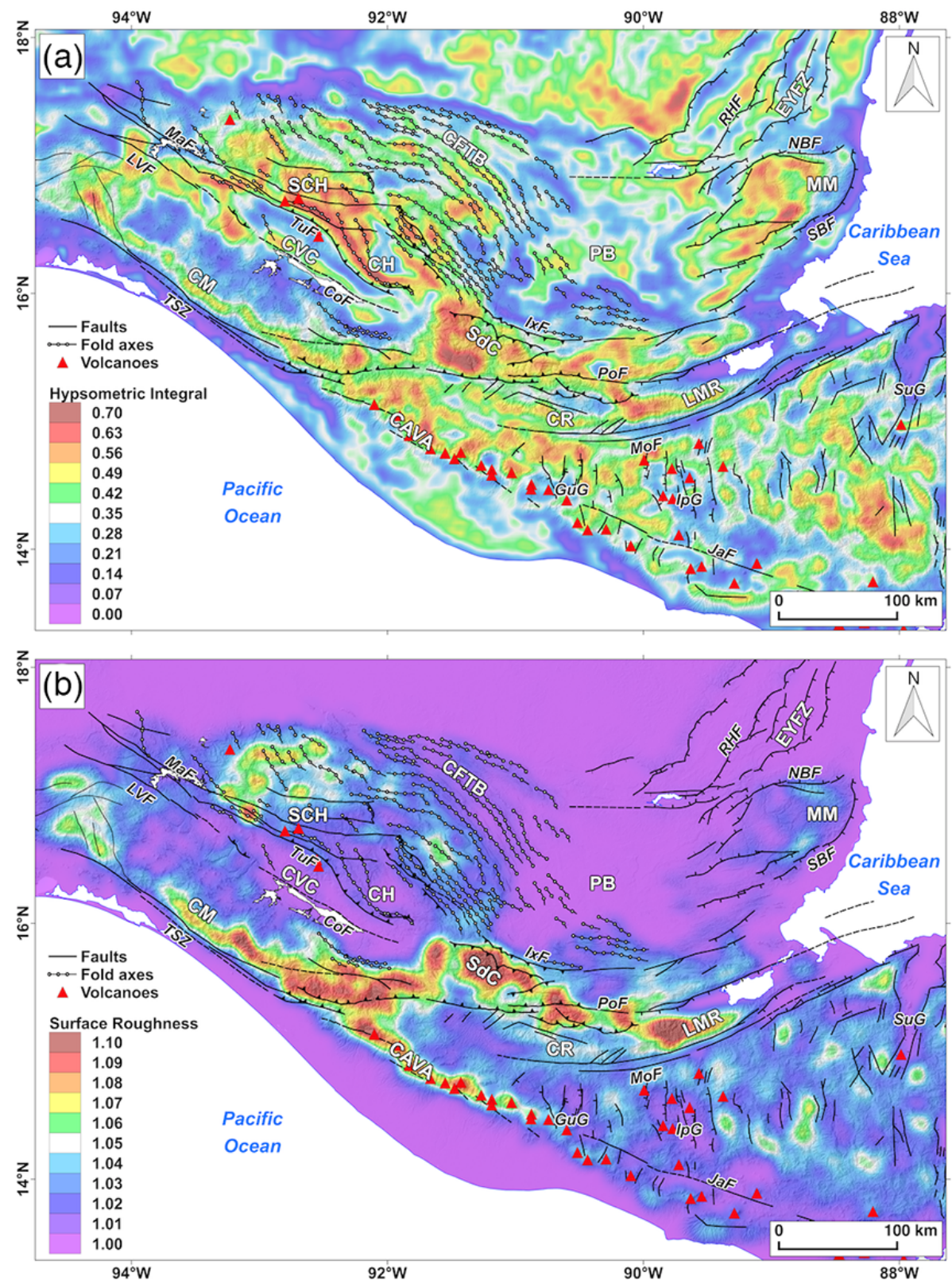

Figure 7. Hypsometric integral (a) and surface roughness (b) for northern Central America. See Fig. 2 for abbreviations.

of the Central American volcanic arc as well as the relatively flat landscapes of the Petén Basin and Yucatán platform. In other areas, the distribution of the low-relief landscapes appears more fragmented. This is the case for the areas located between the Ixcán and Motagua faults, where our maps highlight the remnants of the Mayan paleosurface described by Brocard et al. (2011).

We propose to compare the distribution of geomorphic indices (Figs. 7 and 8), precipitation data (Fig. 5b) and geological contours (Fig. 2b) within the Sierra Madre de Chiapas. Our aim is to detect possible effects of climate or lithology on the location of incised areas and low-relief surfaces. At a first glance, peaks in precipitation (Fig. 5a) seem to coincide with more rugged topography (along the Pacific coast, the northern Sierra de Chiapas and the eastern part of the Sierra de los Cuchumatanes). However, peaks in precipitation are mainly located at the limits of the orogenic belt, while the rugged topography is observed in both external and inner parts of the orogen. On top of that, some areas display a rugged topography in spite of relatively low precipitation (e.g., west of the Sierra de los Cuchumatanes) and vice versa (e.g., eastern part of the Chiapas fold-and-thrust belt). To compare the distribution of precipitation and geomorphic indices, we randomly selected 20000 points within the Sierra Madre de Chiapas. 

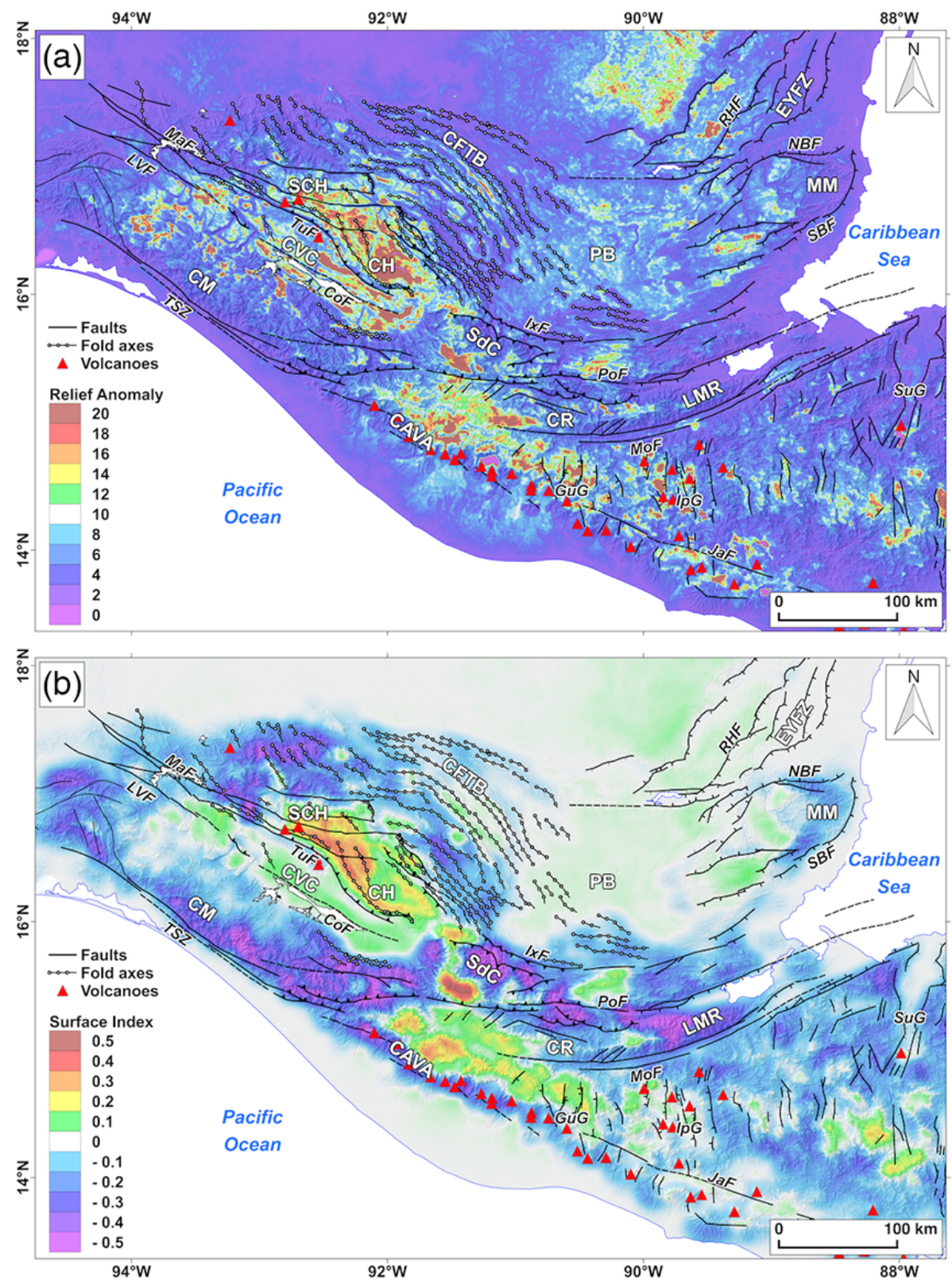

Figure 8. Relief anomaly (a) and surface index (b) for northern Central America. See Fig. 2 for abbreviations.

For each point we extracted the corresponding pixel values from surface roughness, surface index, hypsometric integral, local relief and precipitation maps. We then compared the distribution of the values using scatterplots (Fig. 9). The colinearity of the scatterplots was estimated using the Pearson correlation coefficient (PCC). PCC values vary between +1 and -1 ( 1 is total positive correlation, 0 is no correlation, and -1 is total negative correlation). PCC values for plots of precipitation against several geomorphic indices (Fig. 9) suggest no significant correlation between the amount of precipitation and the ruggedness of the landscape.
We also compared the distribution of geomorphic indices for different geological units. We made three sets of points located within the Sierra Madre de Chiapas. Each set of points corresponds to one of the main geological units of the Sierra Madre de Chiapas: the Paleogene terrigenous deposits, the Cretaceous limestones and the Permian granodiorite of the Chiapas Massif (Fig. 2). For each point we extracted the corresponding surface roughness, surface index, hypsometric integral and local relief value. Histograms in Fig. 10 reveal slight changes in the distribution of the geomorphic indices which may be related to an effect of lithology. Cretaceous carbonates show lower surface roughness values when com- 

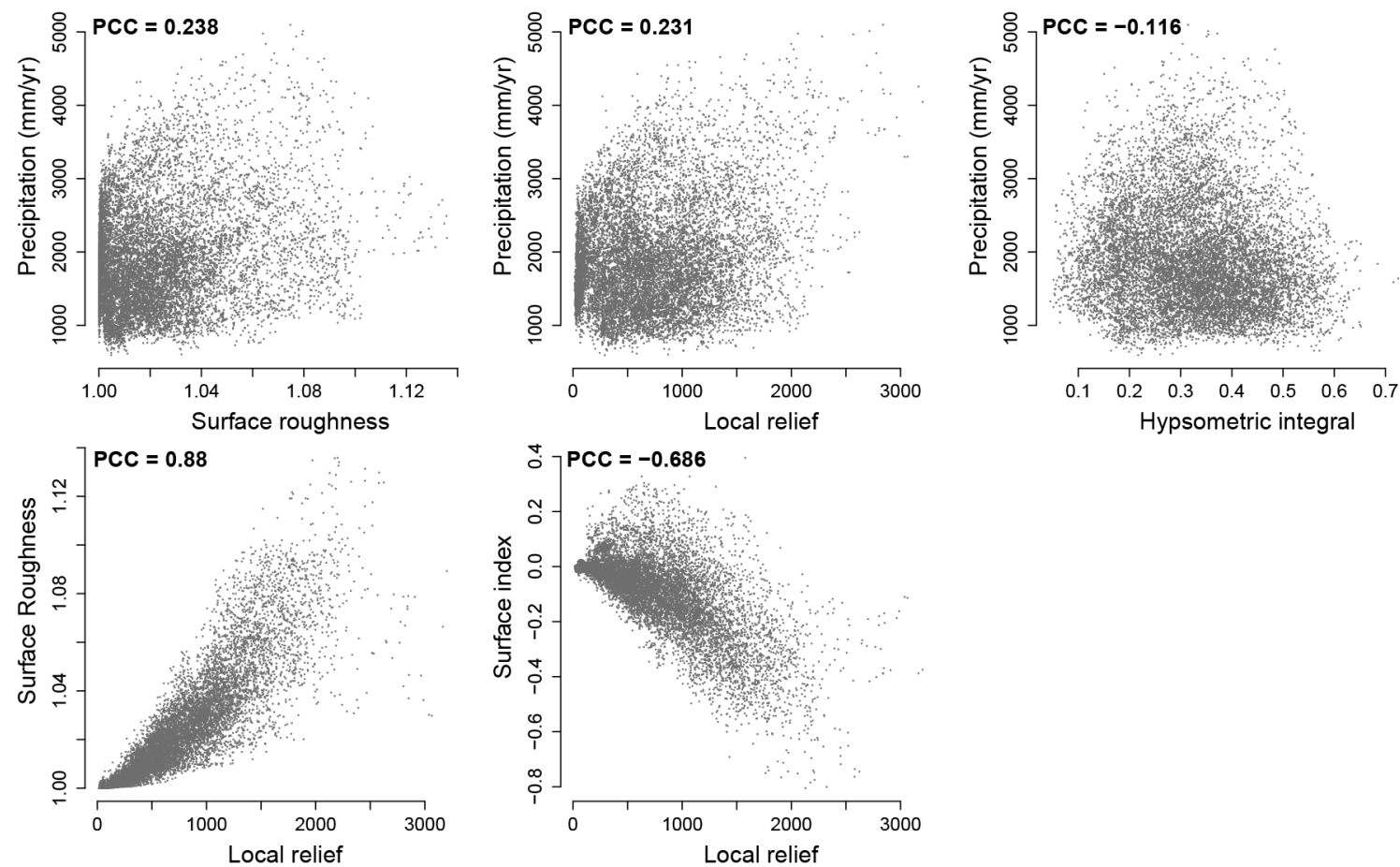

Figure 9. Comparison between precipitation (derived from TRMM data) and morphometric indices within the Sierra Madre de Chiapas. Points represents pixel values extracted from the precipitation (Fig. 5b) and morphometric maps (Figs. 7 and 8). The linear correlation between the variables was estimated using the Pearson correlation coefficient (PCC).
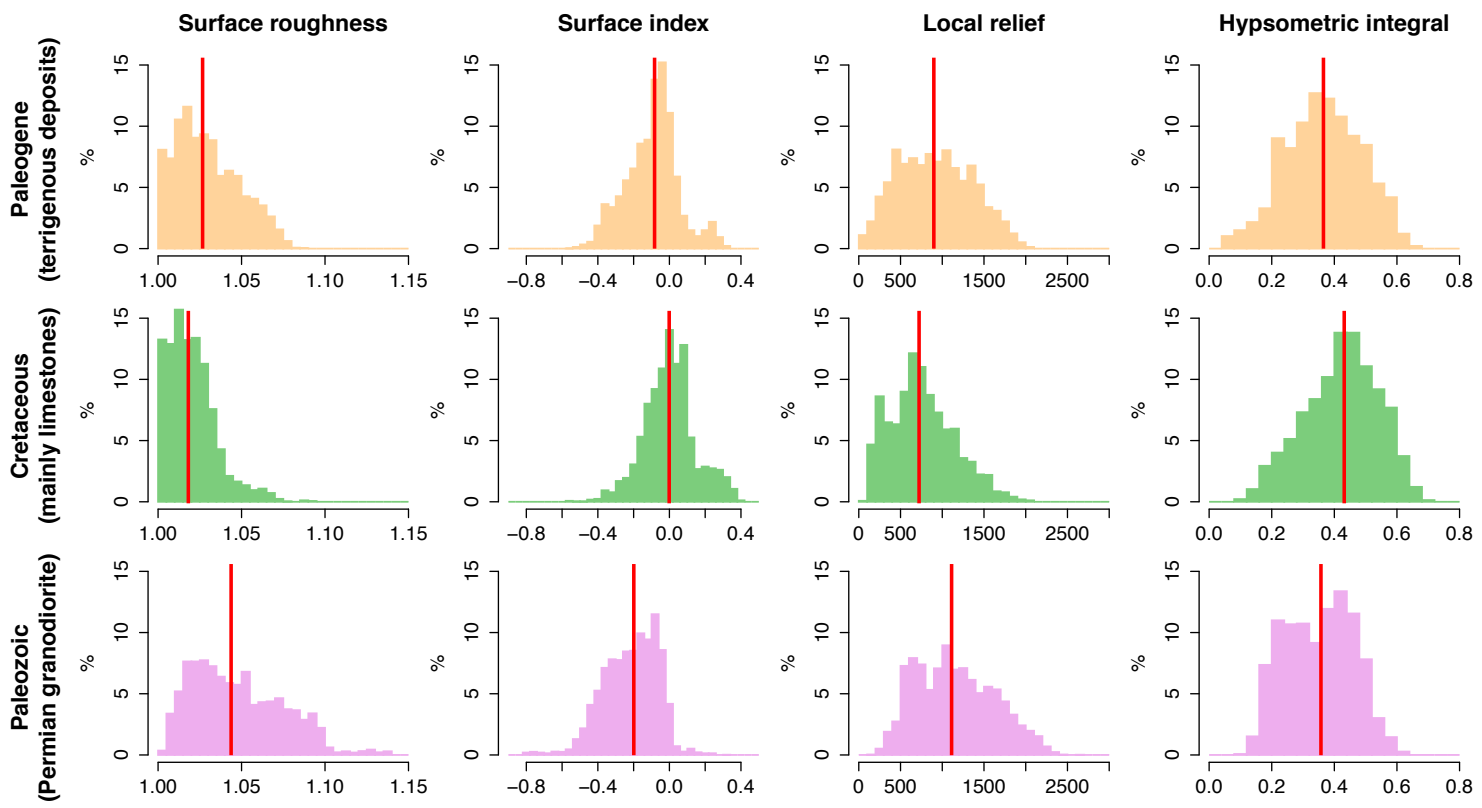

Figure 10. Distribution of morphometric indices for the main lithological groups of the Sierra Madre de Chiapas. Histograms are based on three sets of 5000 pixel values extracted from the morphometric maps (Figs. 7 and 8). Red line represents the median.

pared to Paleogene deposits or Permian rocks. Most of the Permian granodiorite displays negative surface index values. Cretaceous carbonates show slightly lower local relief and higher hypsometric integral values.

\subsection{River longitudinal profiles}

Topographic uplift, subsidence or climatically induced sealevel changes modify the base level of rivers and result in 

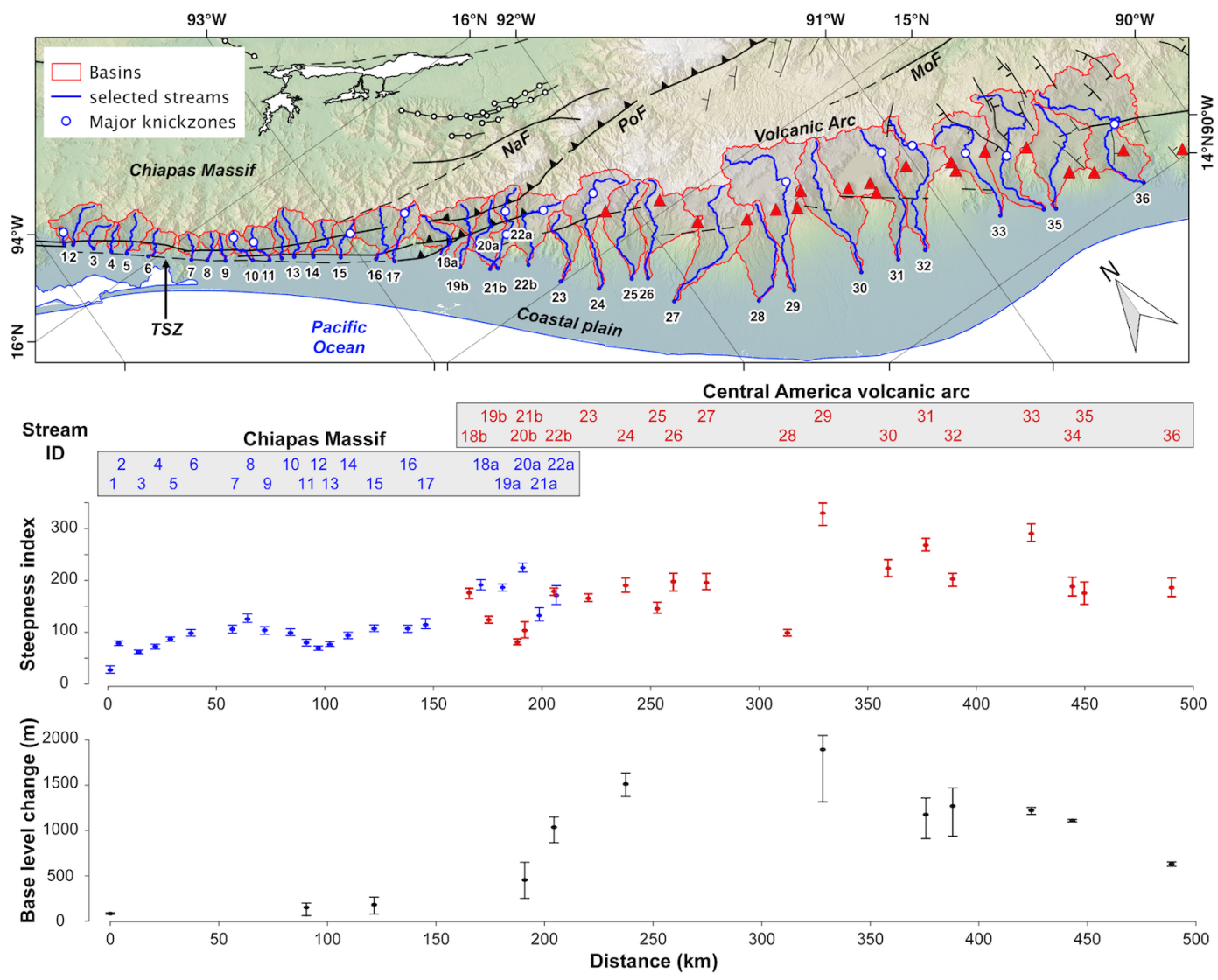

Figure 11. Analyzed streams in Chiapas Massif and Central American volcanic arc. Top: location map. Blue lines represent channels extracted from the modeled drainage network. White dots represent major knickzones. Red lines show limits of catchments. Black lines and red triangles represent main faults and active volcanoes, respectively. Bottom: plot of steepness index $\left(k_{\mathrm{sn}}\right)$ values and estimated base-level changes along a profile passing through the outlet of each catchment. Abbreviations: MoF - Motagua Fault; NaF - Necta Fault; PoF Polochic Fault; TSZ - Tonalá shear zone.

the progressive erosion or rejuvenation of pre-existing topographic features through time. Thus, the analysis of deviations from the typical concave-up shape of stream longitudinal profiles (i.e., knickpoints or convex segments) is a suitable approach to explore these phenomena.

\subsubsection{Tonalá shear zone and volcanic arc}

We analyzed 36 rivers draining the western flank of the Chiapas Massif and the Central American volcanic arc (Fig. 11). We focused our analysis on the areas located between the main drainage divide and the alluvial Pacific coastal plain. Longitudinal profiles were extracted from the modeled drainage network (Figs. 11 and 12).

Figure 12 displays characteristic stream profiles. Longitudinal profiles 6 and 15 (Fig. 12) are representative of main trunk rivers located upstream of the Tonala shear zone (streams and catchments 1-17 in Fig. 11). The shear zone marks the boundary between the Permian batholith of the Chiapas Massif to the northeast and the Pacific coastal plain to the southwest. Two-thirds of the analyzed rivers display a rather smooth and graded longitudinal profile with a single concave segment (such as profile 6 in Fig. 12). The remaining rivers display a gentle knickzone which separates two main segments (such as profile 15 in Fig. 12). Profiles 23-36 (Fig. 11) drain the Central American volcanic arc domain. Half of the analyzed rivers display a prominent knickzone (such as profile 24 in Fig. 12) which separates a gently concave upper reach from a steeper lower reach. Profiles 18-22 (Fig. 11) are located within a transition zone between the two previous regions, where the NW-trending Tonalá shear zone connects to the E-trending Polochic fault system along a WNW-tending fault zone. The longitudinal profiles of streams 21 and 22 display two main knickzones (see profile 21 in Fig. 12). The upper knickzone extends a few kilometers upstream of the fault which makes the junction between the Tonala shear zone and the Polochic fault system. However, the lower knickzone appears more prominent and thus seems to be associated with a larger base-level change.

We extracted two parameters from analyzed longitudinal profiles in order to illustrate the along-strike changes in the 
Longitudinal profile No. 6
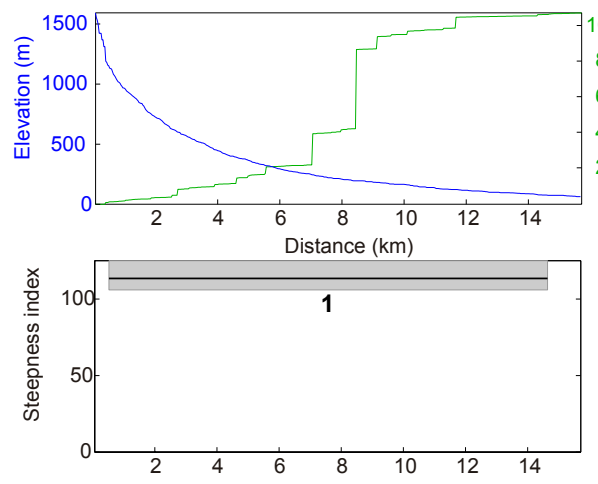

Distance $(\mathrm{km})$

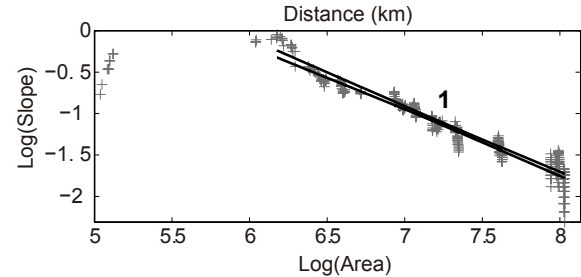

Longitudinal profile No. 21
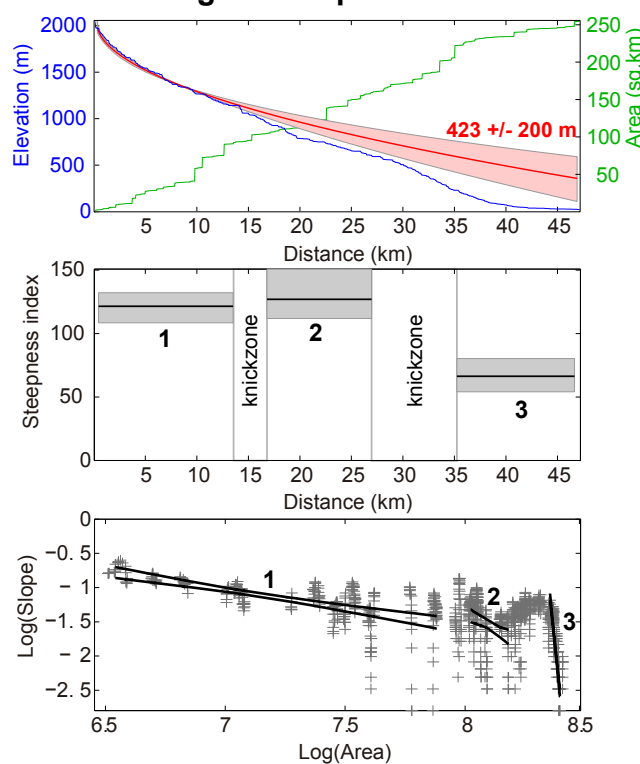

Longitudinal profile No. 15
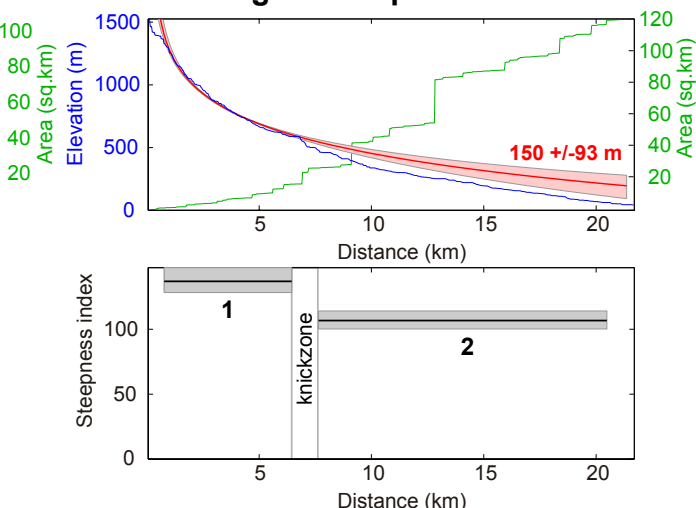

Distance $(\mathrm{km})$

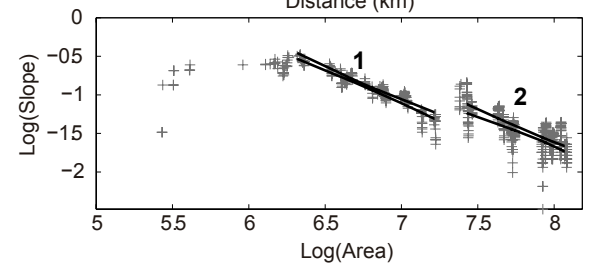

Longitudinal profile No. 24
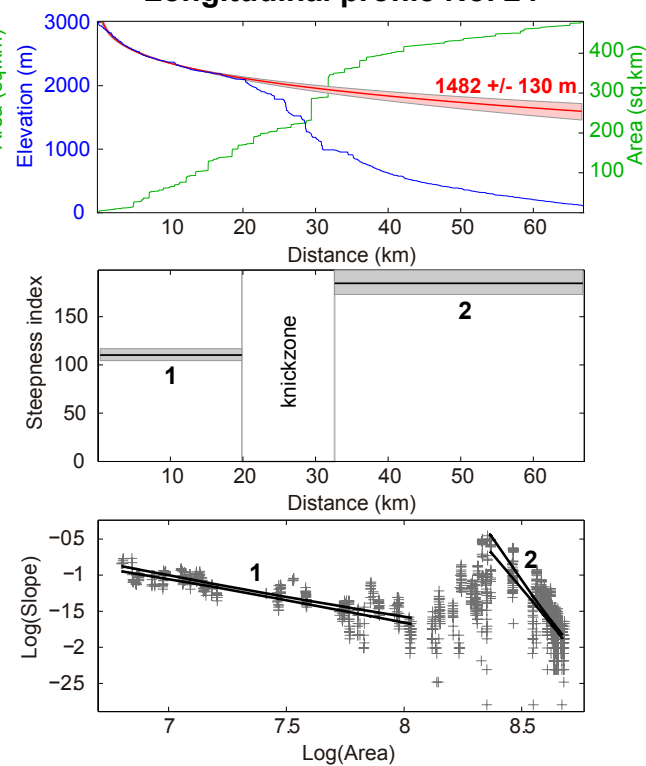

Figure 12. Examples of stream profiles extracted from the modeled drainage network in Chiapas Massif and volcanic arc. Upper plots: blue lines represent longitudinal profiles, green lines show the contributing area (flow accumulation), red lines show reconstructed profiles (interpolation of the slope-distance relation from segments above the upper knickzones; see Eq. 7) and pink polygons represent the uncertainties (based on a bootstrapping method). Central plots: black lines represent extracted steepness index $\left(k_{\mathrm{sn}}\right)$ values for a given segment and grey polygons show the uncertainties (based on a bootstrapping method). Lower plots: logarithmic plots of slope vs. area (grey crosses) and envelopes of regressions (black lines) used to estimate the $k_{\mathrm{Sn}}$ values.

geometry of rivers. The first one is the steepness index $\left(k_{\mathrm{sn}}\right)$ extracted from logarithmic plots of slope against area (see examples in Fig. 12). Graded profiles show a single $k_{\text {sn }}$ value, while non-equilibrated profiles are characterized by changing $k_{\mathrm{sn}}$ values associated with several segments. In this latter case we considered the $k_{\mathrm{sn}}$ value of the lowermost segment as it is the one along which rivers adjust to new base-level conditions (e.g., Kirby and Whipple, 2001; Wobus et al., 2006; Whittaker et al., 2008). The second parameter is the estimated base-level change. If the profile displayed a welldefined upper reach, we projected the segment located above the knickzone using a logarithmic plot of slope against distance (see Eq. 7). We then estimated the base-level change according to the difference in elevations between the pro- 

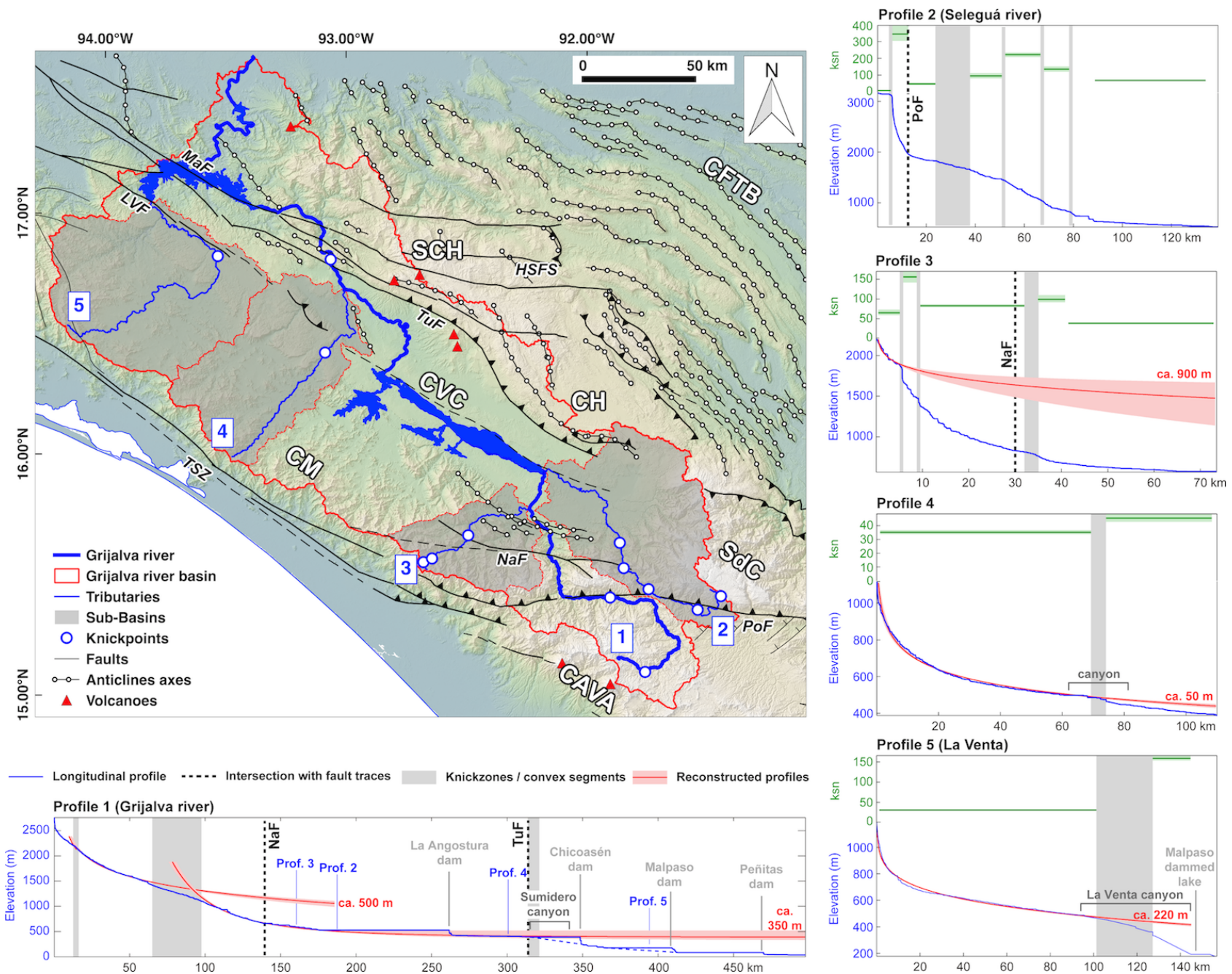

Figure 13. Longitudinal profiles for the Grijalva River and the tributaries from the Sierra de los Cuchumatanes and Chiapas Massif. Profiles were extracted from the modeled drainage network. See Fig. 2 for faults abbreviations and Fig. 12 for plot description.

jected and the actual profiles at the outlet (see examples in Fig. 12).

Both $k_{\mathrm{sn}}$ values and estimated base-level changes were plotted along a profile passing through the outlets of the analyzed catchments (Fig. 11). The results suggest a substantial along-strike increase in $k_{\mathrm{sn}}$ values, from $\sim 100$ along the northern tip of the Chiapas Massif to $>200$ along the volcanic arc. Estimated base-level changes seem to be low for the Chiapas Massif $(<200 \mathrm{~m}$ ) but increase significantly along the southern tip of the Tonalá shear zone (where it connects to the E-trending Polochic Fault) and are higher within the volcanic arc (1000-2000 m).

\subsubsection{Grijalva River}

The Grijalva River (profile 1 in Fig. 13) flows from the northern tip of the volcanic arc towards the Tabasco coastal plain. Two main knickzones are located upstream of the Necta
Fault. They mark the transition between the elevated volcanic arc plateau, the back-arc domain and the local base level of the central depression of Chiapas. The reconstructed profile made using the segment located above the lowest knickzone suggests $\mathrm{a} \sim 500 \mathrm{~m}$ base-level fall between the backarc domain and the central depression of Chiapas. Segments located within the central depression of Chiapas (between the Necta and Tuxtla faults) and the Tabasco coastal plain display a lower gradient in comparison with those located upstream of the Necta Fault. Despite numerous artifacts related to hydroelectric dams (e.g., La Angostura, Chicoasén and Malpaso dams) and canyons (e.g., Sumidero), we can infer a major knickzone located between the Tuxtla Fault and the Chicoasén dam. We attempted to infer the geometry of the Grijalva River profile using the segments upstream and downstream of the flooded areas. The segments of the river upstream and downstream of La Angostura dammed lake could be fit by the same regression in a logarithmic plot of 

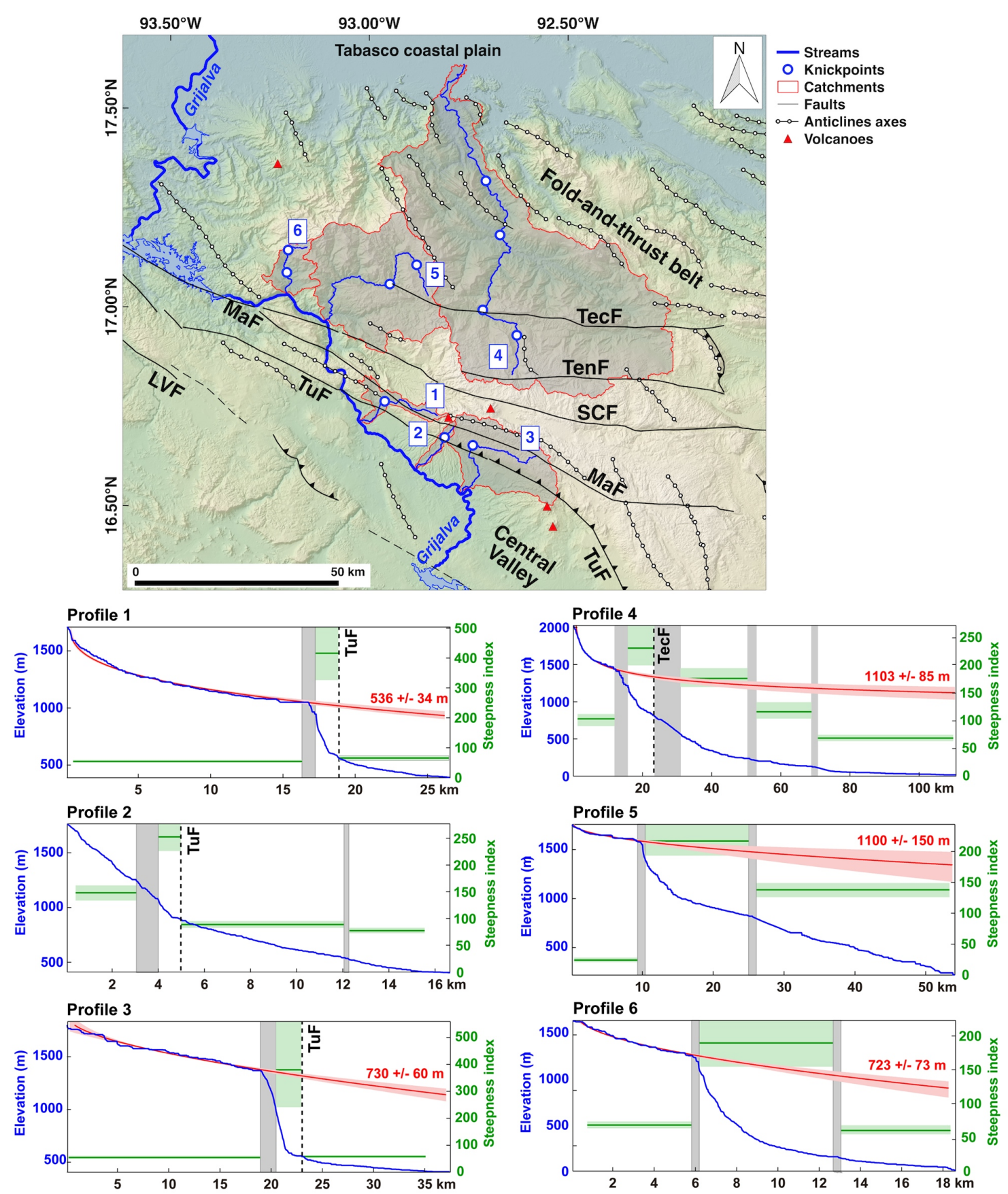

Figure 14. Longitudinal profiles for the Sierra de Chiapas. Channels and profiles were extracted from the modeled drainage network. See Fig. 12 for plot description. Abbreviations: LVF - La Venta Fault; MaF - Malpaso Fault; SCF - San Cristobal Fault; TecF - Tectapan Fault; TenF - Tenejapa Fault; TuF - Tuxtla Fault.

slope vs. area (see profile 1 in Fig. 13). We are confident that no knickpoints are hidden below this dammed lake (otherwise it would have been witnessed through a change in gradient of the river). In contrast, the gradient of the river upstream and downstream of the Chicoasén dammed lake differ and cannot be fit by a single regression. The gradient of the Grijalva River is $200 \mathrm{~m}$ between the Tuxtla Fault and the
Chicoasén Dam ( $\sim 30 \mathrm{~km}$ apart), while it is less than $50 \mathrm{~m}$ between La Angostura Dam and the Tuxtla Fault $(\sim 60 \mathrm{~km}$ apart). We thus suspect that the Chicoasén dammed lake hides a major flooded knickzone which marks a $\sim 350 \mathrm{~m}$ base-level fall between the central depression of Chiapas and the Tabasco coastal plain. For the Malpaso and Peñitas dams 
the gradient of the river became too low and the scatter in slope-area data too high to make such tests.

The Seleguá River (profile 2 in Fig. 13) is a right-bank tributary of the Grijalva River which flows from the southern tip of the Sierra de los Cuchumatanes into the central depression of Chiapas. A prominent knickzone is observed upstream of the Polochic Fault. This knickzone separates an upper segment with a gentle gradient $\left(k_{\mathrm{sn}}<50\right)$ from a lower and much steeper $\left(k_{\mathrm{sn}}>300\right)$ segment. The upper segment is associated with the relicts of the mid-Miocene Mayan paleosurface which is preserved on top of the Sierra de los Cuchumatanes (Authemayou et al., 2011). Downstream of the Polochic Fault the profile displays an overall convex shape related to numerous knickzones. The lowermost segment is located within the central depression of Chiapas and shows a gentle gradient.

Longitudinal profiles 3-5 (Fig. 13) are from left-bank tributaries located within the Chiapas Massif. Longitudinal profile 3 (southern tip of the Chiapas Massif) displays two prominent knickzones. The upper knickzone is located close to the drainage divide and separates an upper segment with a gentle gradient $\left(k_{\mathrm{sn}}<75\right)$ from a lower and much steeper $\left(k_{\mathrm{sn}}>150\right)$ segment. The lower knickzone is more gentle and located downstream of the Necta fault trace. Profiles 4 and 5 intersect the lineament made by the La Venta and Concordia faults. In both profiles the upper reach $(60-80 \mathrm{~km}$ from the drainage divide) is gently concave $\left(k_{\mathrm{sn}}\right.$ values around 30). The upper segments are limited downstream by a knickzone which corresponds both to the boundary between the Chiapas Permian batholith and the Cretaceous/Tertiary sedimentary cover and to the La Venta-Concordia lineament. In both profiles the knickzone is associated with canyons as the river incised through the sedimentary cover (mainly Cretaceous limestones). In profile 4 this knickzone marks a minor base-level fall (approximately $50 \mathrm{~m}$ ) between the upper reach and the central depression of Chiapas. In profile 5 the knickzone is associated with a major base-level fall as the lower reach connects to the portion of the Grijalva River which is in equilibrium with the base level of the Tabasco coastal plain. The reconstruction of the upper reach suggests approximately $200 \mathrm{~m}$ base-level fall. However, the lower part of the tributary is flooded by the Malpaso dammed lake and the real base-level fall could be higher.

\subsubsection{Sierra de Chiapas}

Figure 14 displays river longitudinal profiles from the northern part of the Sierra de Chiapas. Profiles 1-3 are characteristic of the tributaries of the Grijalva River flowing across the Tuxtla Fault. Almost all longitudinal profiles display prominent knickzones located upstream of the fault scarp. Upper reaches display either a smooth concave shape (as in profiles 1 and 3, Fig. 14) or a convex shape (as in profile 2). Convex upper reaches are mainly observed in the areas where the fault trace intersect volcano-sedimentary deposits related to

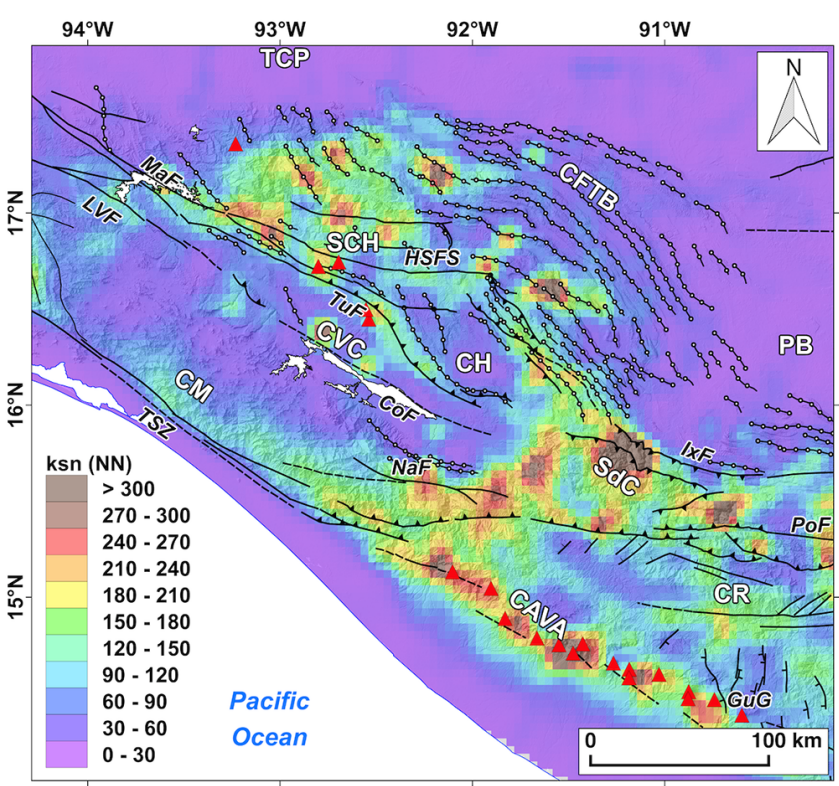

Figure 15. Interpolated map of steepness index $\left(k_{\mathrm{sn}}\right)$ for the Sierra Madre de Chiapas and the northern segment of the Central American volcanic arc. Values were extracted from river longitudinal profiles using $5 \mathrm{~km}$ long segments and interpolated using a natural neighbor (NN) method. See Fig. 2 for abbreviations.

Plio-Quaternary volcanoes or in the area where the fault trend change from NW to NNW. The lower reaches are strongly concave and are associated with higher $k_{\mathrm{sn}}$ values. Reconstructions of upper reaches (profiles 1 and 3 in Fig. 14) suggest a 500-800 m base-level change along the Tuxtla fault scarp.

Longitudinal profiles 4-6 are located within the northern parts of the Sierra de Chiapas. They are complex, as rivers flow through the E-trending left-lateral faults and then through the NW to NNW-trending structures of the Chiapas fold-and-thrust belt. As a result, these profiles display several knickzones (e.g., profile 4 in Fig. 14). However, the upper knickzones are more prominent as they mark a sharp transition between the uppermost segments characterized by gentle gradients and low $k_{\text {sn }}$ values $(<100)$ and the lower segments which show steeper gradients and higher $k_{\text {sn }}$ values (between 150 and 250). Reconstructions of upper reaches suggest a $700-1100 \mathrm{~m}$ base-level change with respect to the Grijalva River (profiles 5 and 6 in Fig. 14) or the Tabasco coastal plain (profile 4 in Fig. 14).

\subsubsection{Steepness index map}

The analysis of river longitudinal profiles shows that major base-level changes (i.e., higher than $100 \mathrm{~m}$ ) are associated with prominent knickzones and to a substantial increase in steepness index $\left(k_{\mathrm{sn}}\right)$ values. We thus propose to map the variations in $k_{\mathrm{sn}}$ values within the Sierra Madre de Chiapas in order to assess the locations of main drainage network pertur- 

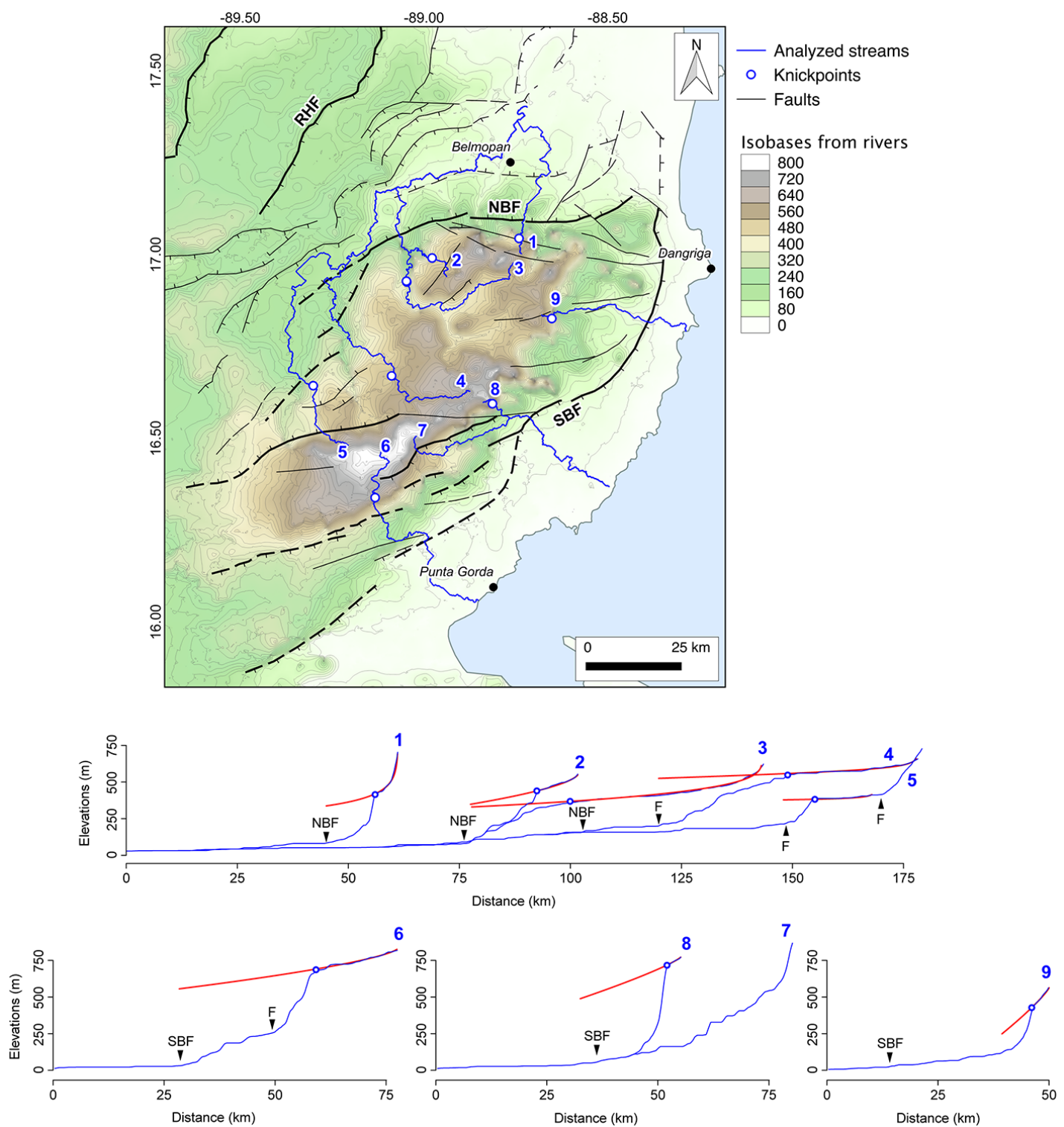

Figure 16. Analysis of drainage network for the Maya Mountains. Top: map of isobases (i.e., interpolated elevations) from rivers with a Strahler order $\geq 2$. Main faults (black lines), analyzed streams (blue lines) and main knickpoints (blue dots) are also reported. Bottom: longitudinal stream profiles. Blue dots are main knickpoints (location on the map). Red lines show profiles reconstructed using segments located above the knickpoints (see Eq. 7). Black arrows show the intersection with main faults. Abbreviations: NBF - northern boundary fault; SBF - southern boundary fault; RHF - Rio Hondo Fault; F - other faults.

bations. We computed $k_{\mathrm{sn}}$ values from extracted river profiles using a $5 \mathrm{~km}$ moving window. We then interpolated obtained values using a natural neighbor $(\mathrm{NN})$ method. The result is shown in Fig. 15.

The overall distribution of $k_{\mathrm{sn}}$ appears to be tectonically controlled, as highest values are found close to major tectonic features. In Chiapas, highest $k_{\mathrm{sn}}$ values (>150 in Fig. 15) are mainly distributed along the Tuxtla Fault, the E-trending strike slip faults of the Sierra de Chiapas and the portion of the fold-and-thrust belt located north of the Sierra de Chiapas. Areas located along the La Venta Fault and the Tonalá shear zone display intermediate $k_{\mathrm{sn}}$ values $(90-120)$. Uniformly low $k_{\mathrm{sn}}$ values suggest that most of the tributaries of the Grijalva River flowing in the northern part of the Chiapas Massif and the Central Valley of Chiapas share a common base level.

To the south, the Polochic Fault exerts a strong control over the drainage network. The Sierra de los Cuchumatanes and the SE tip of the Chiapas Massif (limited by the Polochic Fault to the south and the Ixcán and Necta faults to the north) display especially high values (>180). By contrast, most of the areas located south of the Polochic Fault are as- 
sociated with lower $k_{\mathrm{sn}}$ values $(<150)$. Lowest $k_{\mathrm{sn}}$ values $(<90)$ are found within the back-arc region and the graben of Guatemala City. The last area displaying high $k_{\mathrm{sn}}$ values ( $>180$ in Fig. 15) corresponds to the SW flank of the Central American volcanic arc where rivers are affected by a very steep topographic gradient.

\subsubsection{Maya Mountains}

We analyzed the drainage network of the Maya Mountains using a map of isobases from rivers and several longitudinal profiles (Fig. 16). Longitudinal profiles 1-5 (Fig. 16) are part of the Belize River watershed, which drains the northern and western side of the Maya Mountains. All these profiles display prominent knickpoints which mark the transition between the upper reaches, which are usually gently concave, and the lower segments, which are either concave with a steeper gradient or convex. The knickpoints are located upstream of the ENE- to E-trending northern boundary fault for profiles 1-3 (Fig. 16) and upstream of a NE-trending fault zone in profiles 4 and 5 (Fig. 16). The reconstructed profiles made using the upper reaches suggest that the drainage network faced a $300-500 \mathrm{~m}$ base-level change.

Profiles 6-9 (Fig. 16) are located in the southern and eastern parts of the Maya Mountains and flow directly into the Caribbean sea. Only southernmost profiles display prominent knickpoints which delimitate a well-defined upper reach (e.g., profile 6 in Fig. 16). These knickpoints are located upstream of the NE-trending southern boundary fault and a ENE-trending fault zone. By contrast, most of the profiles located along the eastern side of the Maya Mountains display an almost smooth and concave shape such as profile 7 (Fig. 16). In particular, there is no significant change in the gradient of the rivers along the southern boundary fault. However, in some cases a knickpoint associated with a relict upper reach is found close to the drainage divide (profiles 8 and 9 in Fig. 16). The reconstructed upper reaches in profiles 5 and 8 (Fig. 16) suggest a $500 \mathrm{~m}$ base-level change.

Isobases from rivers (Fig. 16) allows for the geometry of the drainage network to be summarized. Within the Maya Mountains, the isobase surface forms a roughly sigmoidalshaped plateau. Spaced contour lines indicate gentle gradient in rivers flowing in the central part of the range. The top of the isobase surface is more elevated $(>800 \mathrm{~m})$ in the southern part of the Maya Mountains (between 16.30 and $16.60^{\circ} \mathrm{N}$ ), where it forms a flat structural high delimited by two parallel ENE-trending fault zones. North of $16.60^{\circ} \mathrm{N}$, the top of the isobase surface rather forms a tilted panel, with elevations decreasing towards the NW (from ca. 700 to ca. $400 \mathrm{~m}$ ). The isobase surface of this tilted panel is almost flat but the drainage network of the Macal River (stream 3 in Fig. 16) appears entrenched with elevations ca. $200 \mathrm{~m}$ below the average elevation of the isobase surface. This can also be observed in swath profiles (Fig. 6) crossing this drainage basin. The western and northern sides of the tilted north- ern panel are controlled by major structures, as indicated by sharp isobase gradients associated with a NE-trending fault zone and with the ENE- to E-trending northern boundary fault. Areas located along the northern segment of the southern boundary fault appear significantly incised and the top of the isobase surface is located ca. $25 \mathrm{~km}$ east of this fault.

\section{Discussion}

\subsection{Equilibrium of landscapes}

The evolution of landscapes results from complex interactions between climatic and tectonic processes (e.g., Hack, 1960; Willett and Brandon, 2002; Matmon et al., 2003; Pazzaglia, 2003; Ferrater et al., 2015, and the references therein). Recent tectonic or climatically induced base-level fall are associated with the propagation of an erosion wave, which represents the limit between an upper-relict landscape and a lower adjusting zone (e.g., Reinhardt et al., 2007; PérezPeña et al., 2015). As a result, relict portions of landscapes (i.e., where uplift is not yet counterbalanced by fluvial erosion) may persist though time (e.g., Burbank and Anderson, 2001; Clark et al., 2005; Legrain et al., 2014; Giletycz et al., 2015).

Previous works indicate the occurrence of such relict landscapes along the Polochic-Motagua fault system and within the Chortis block (western corner of the Caribbean Plate). Rogers et al. (2002) interpreted the topography of the northern Central America highlands (east of the modern volcanic arc and south of the Motagua Fault) as an uplifted ignimbritic plateau (Fig. 17). More recently, Brocard et al. (2011) and Authemayou et al. (2011) described a relict middle Miocene planation surface (the so-called "Mayan paleosurface") which covered most of the areas between the Ixcán and Motagua faults (Fig. 17) and was subsequently uplifted and deformed. Our results suggest that relict landscapes are also preserved within the Sierra Madre de Chiapas and Maya Mountains. Topographic profiles (Figs. 5 and 6) and both relief anomaly and surface index maps (Fig. 8) highlight elevated areas which are characterized by a low-amplitude relief. These areas are surrounded by more dissected landforms which are characterized by high surface roughness values (Fig. 7). The surface index map (Fig. 8) shows very well this dual distribution of elevated and low-relief (positive values in Fig. 8) and dissected (negative values in Fig. 8) landforms. This is a clear indication that landscapes within the Sierra Madre de Chiapas and Maya Mountains are in a transient stage, and morphometric maps allows for discriminating between the areas forming part of an upper-relict landscape and the propagating front of river incision. Moreover, river longitudinal profiles display an upper reach associated with these relict landscapes, while lower segments represent one or several knickzones along which channels adjust to new baselevel conditions. 


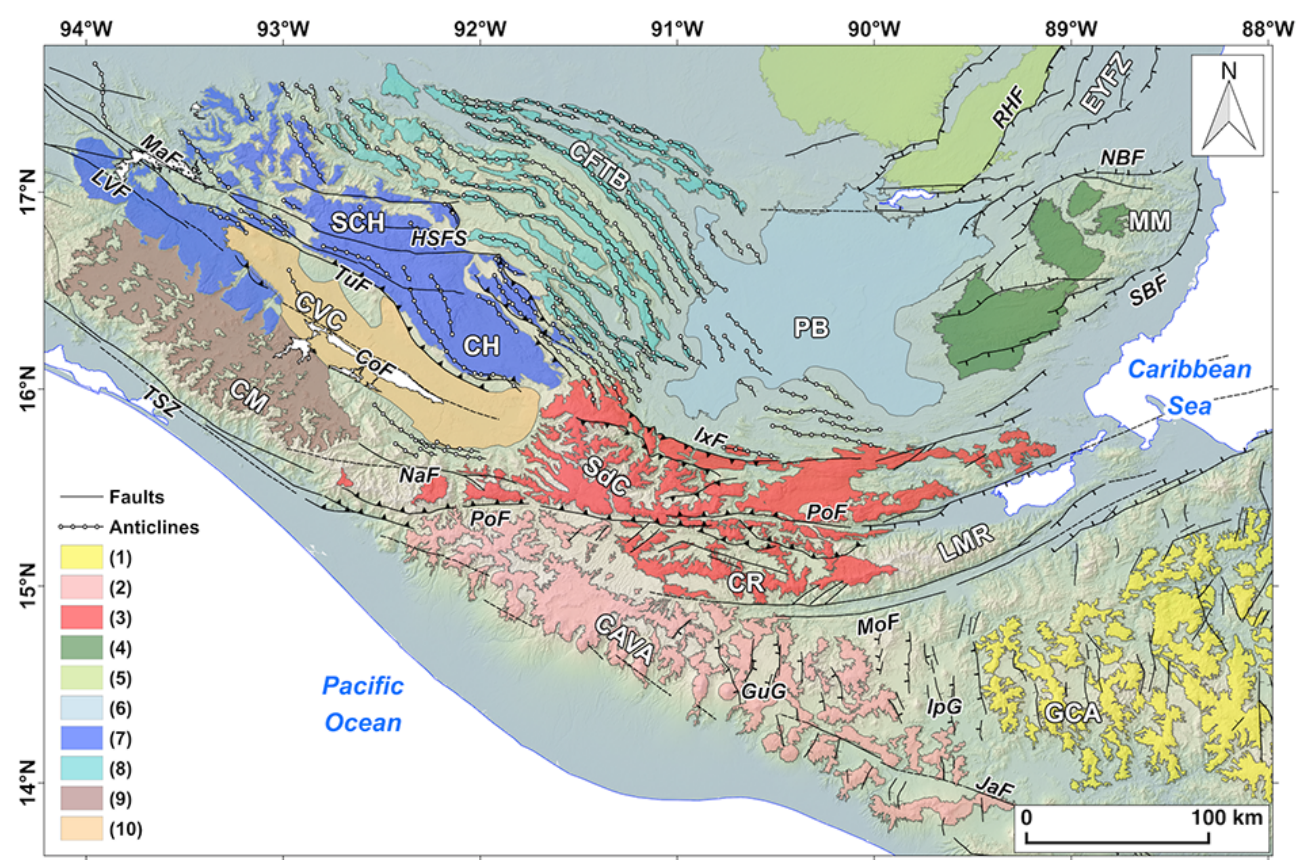

Figure 17. Proposed extension of elevated surfaces and relict landscapes in northern Central America (interpretative map based on morphometric maps, Figs. 7 and 8). Legend: 1 - remnants of the Miocene ignimbritic plateau (Rogers et al., 2002); 2 - Plio-Quaternary volcanic arc plateau; 3 - middle Miocene Mayan paleosurface (Authemayou et al., 2011; Brocard et al., 2011); 4 - relict landscape of the Maya Mountains; 5 - tilted surfaces of the Yucatán platform; 6 - Petén Basin; 7 - elevated plateaus of La Venta and northern Sierra Madre de Chiapas; 8 - inferred extension of the plateau within the fold-and-thrust belt; 9 - monadnock landscape developed over the Chiapas batholith; 10 Central Valley of Chiapas. See Fig. 2 for faults and morphotectonic domain abbreviations.

Our results suggest a limited effect of climate. Within the Sierra Madre de Chiapas we found no clear correlation between peaks in precipitation and the distribution of rugged topography. There is no scaling between the amount of precipitation and the ruggedness of the topography or the amount of incision (Fig. 9). We observe a clear orographic effect on precipitation (swath profiles in Fig. 6). This effect is confined to the borders of the orogen and may locally be superimposed to a rugged topography. However, the incision by the drainage network extends more inward where precipitation is not significantly different from the surrounding coastal plains. The erosion is related to the uplift of the Sierra Madre de Chiapas rather than to a change in climatic conditions. Indeed, recent studies suggest a dominance of tectonics over climate in the denudation of active mountain ranges (e.g., Godard et al., 2014; Fuchs et al., 2015). There is a possible effect of lithology on the location of incised areas and low-relief surfaces. The distribution of morphometric indices suggests slight changes related to lithology (Fig. 10). Lower surface roughness and local relief values observed in Cretaceous limestones are probably related to karst processes. The fact that a part of the drainage is subterranean may have contributed to the extensive preservation of La Venta and Sierra de Chiapas elevated plateaus. By contrast, in other areas where bedrock erosion prevails (for instance within the
Paleogene terrigenous deposits of the northern Sierra de Chiapas), elevated relict landscapes have been deeply incised.

We attempted to map the distribution of elevated relict landscapes from northern Central America (Fig. 17). The surface index and relief anomaly maps (Fig. 8) highlight well areas where elevated and low-relief surfaces are extensively preserved and thus provide a good basis for mapping the extent of relict landscapes. In some areas where elevated surfaces are incised by the drainage network and for the Chiapas Massif where surfaces are nested between ridges, we refined our map using slopes and topographic contours derived from the SRTM data.

Relict landscapes from the Sierra Madre de Chiapas can be divided into four main domains. The westernmost domain consists of a monadnock-type landscape which developed over the Chiapas Massif (Fig. 17). In morphometric maps, this area is characterized by low hypsometric integral and surface roughness values (Fig. 7). In fact, these geomorphic indices respond to an extensive system of large and relatively flat valleys. The drainage system appears in steady state as rivers display smooth concave profiles and low $k_{\mathrm{sn}}$ values (upper segments of profiles 4 and 5 in Fig. 13). The isobase surface of the rivers is almost flat (see curves for minimum elevations in swath profiles 1 and 2, Fig. 6). Such low gradients are characteristic of lowland alluvial rivers. We interpret the topography of the Chiapas Massif as the result of 
a sustained erosion which resulted in the development of a low-relief surface and a system of alluvial valleys. In other words, the Permian batholith of the Chiapas Massif and its sedimentary cover were incised until rivers reached an almost flat and steady-state base level. However, this isobase surface is now located $\sim 400 \mathrm{~m}$ above the present-day sea level. We thus suspect that the topography of the Chiapas Massif was much lower than it is today and that it has been subsequently uplifted.

The large valleys of the Chiapas Massif connects to the east to two morphological domain: the Central Valley of Chiapas and La Venta Plateau (Fig. 17). The eastern boundary of these two domains corresponds to the Tuxtla and Malpaso faults. The Central Valley of Chiapas consists of gently folded tertiary sediments. The topography of this area is smooth as suggested by high-relief anomaly (Fig. 8) and low surface roughness (Fig. 7) values. However, high hypsometric integral values along the Grijalva River reflect an entrenchment of the drainage network. The canyons are filled by the water of the La Angostura dammed lake, but their depth probably did not exceeded $150 \mathrm{~m}$. The Mesozoic carbonates of La Venta Plateau were uplifted and gently tilted along the La Venta and Tuxtla faults. This area is also associated with an entrenchment of the drainage network. The analysis of river longitudinal profiles (Fig. 13) suggests a $\sim 350 \mathrm{~m}$ base-level change between the inner part of the Sierra Madre de Chiapas and the Tabasco coastal plain. We relate the entrenchment of the drainage network within the Central Valley of Chiapas and La Venta Plateau to the uplift of the areas located between the Tuxtla Fault and the Tonalá shear zone. This uplift resulted in an erosional wave propagating upstream within the drainage of the Grijalva River.

The last domain encompasses the elevated plateaus east of the Tuxtla Fault (Comitán High and Sierra de Chiapas, Fig. 17). The northwest part of this plateau is heavily incised as shown by high surface roughness values (Fig. 7). By contrast, the areas south of the Tectapan Fault appear to be less dissected. In spite of elevations up to $2400 \mathrm{~m}$, surface roughness values (Fig. 7) remain low. Indeed, the top of the plateau is associated with a low-relief topography which is disrupted by incisions along the E-trending faults. These differences are probably related to several factors, including lithology (the southern areas consist mainly of Mesozoic carbonates with subterranean drainage limiting surface erosion), climate (the northern areas may receive more precipitation from the Gulf of Mexico), and local base-level changes. The analysis of river longitudinal profiles (Fig. 14) suggests a $\sim 500$ $700 \mathrm{~m}$ base-level change along the Tuxtla Fault and $\sim 700$ $1100 \mathrm{~m}$ in the northern part of the Sierra de Chiapas.

The age of the relict landscapes in Sierra Madre de Chiapas is unknown. Thermochronological and stratigraphic evidence suggests two main periods of topographic growth. The first one occurred during the middle Miocene (16-10 Ma) and the latest one started during the late Miocene-Pliocene and is still ongoing (Guzmán-Speziale and Meneses-Rocha,
2000; Meneses-Rocha, 2001; Ratschbacher et al., 2009; Witt et al., 2012a). We assume that the relict landscapes of the Sierra Madre de Chiapas have developed following the middle Miocene phase of topographic growth. The development of large alluvial valleys within the Chiapas Massif suggests that the Permian batholith and its sedimentary cover were uplifted and significantly eroded until rivers reached an almost flat base level. Indeed, Witt et al. (2012a) show that the middle to late Miocene period is associated with a marked increase in erosion of the Chiapas Massif and sedimentation within the basins of the Tabasco region. The distribution of morphometric indices (Fig. 7) and the location of knickzones upstream of major faults such as the Tuxtla Fault (profiles 1-3 in Fig. 14) indicate that this late Miocene erosional topography was subsequently uplifted and fragmented by tectonics. This probably happened during the latest period of deformation ( $\sim 5 \mathrm{Ma}$ to present). A middle Miocene age for the erosional topography of the Sierra Madre de Chiapas would be consistent with the timing of similar topographic features, such as the so-called "Mayan paleosurface" which covered most of the Polochic-Motagua sliver (Authemayou et al., 2011; Brocard et al., 2011). According to Brocard et al. (2011), this widespread planation surface formed at low elevation during the middle Miocene (between 13 and $7 \mathrm{Ma}$ ).

Our results show that most of the Maya Mountains consist of an elevated relict landscape (Fig. 17). Geomorphic maps (Figs. 7 and 8) as well as isobases from rivers (Fig. 16) indicate that low-relief surfaces have been extensively preserved in the central and western parts of the Maya Mountains, while the eastern part of the range has been more eroded. Most of the analyzed river longitudinal profiles (Fig. 16) display an upper reach associated with these low-relief surfaces. Here again, the age of this relict landscape is unknown. According to Purdy et al. (2003), uplift in the Maya Mountains did not occur until late Neogene and perhaps no earlier than late Pliocene. The low-relief surfaces we observe in the Maya Mountains may have formed during the middle Miocene like the Mayan paleosurface. In the southern part of the range, the low-relief surface of the Maya Mountains gently dips towards the west and seems to connect to the flat topography of the Petén Basin.

\subsection{Morpho-tectonic interpretations}

Landscapes from the Sierra de Chiapas and the Maya Mountains were fragmented and locally rejuvenated by tectonics. We propose to combine our topographic profiles (Figs. 5 and 6), geomorphic maps (Figs. 7 and 8) and analyzed river profiles (Figs. 11-16) with published GPS and seismotectonic data in order to locate main active deformation zones. We attempted to define coherent tectonic blocks (Fig. 18) in order to produce a comprehensive map of the plate boundary.

The Tonalá shear zone has been depicted as a relict leftlateral structure (Wawrzyniec et al., 2005; Weber et al., 2005). Indeed, it shows no signs of seismic activity (Fig. 3b). 

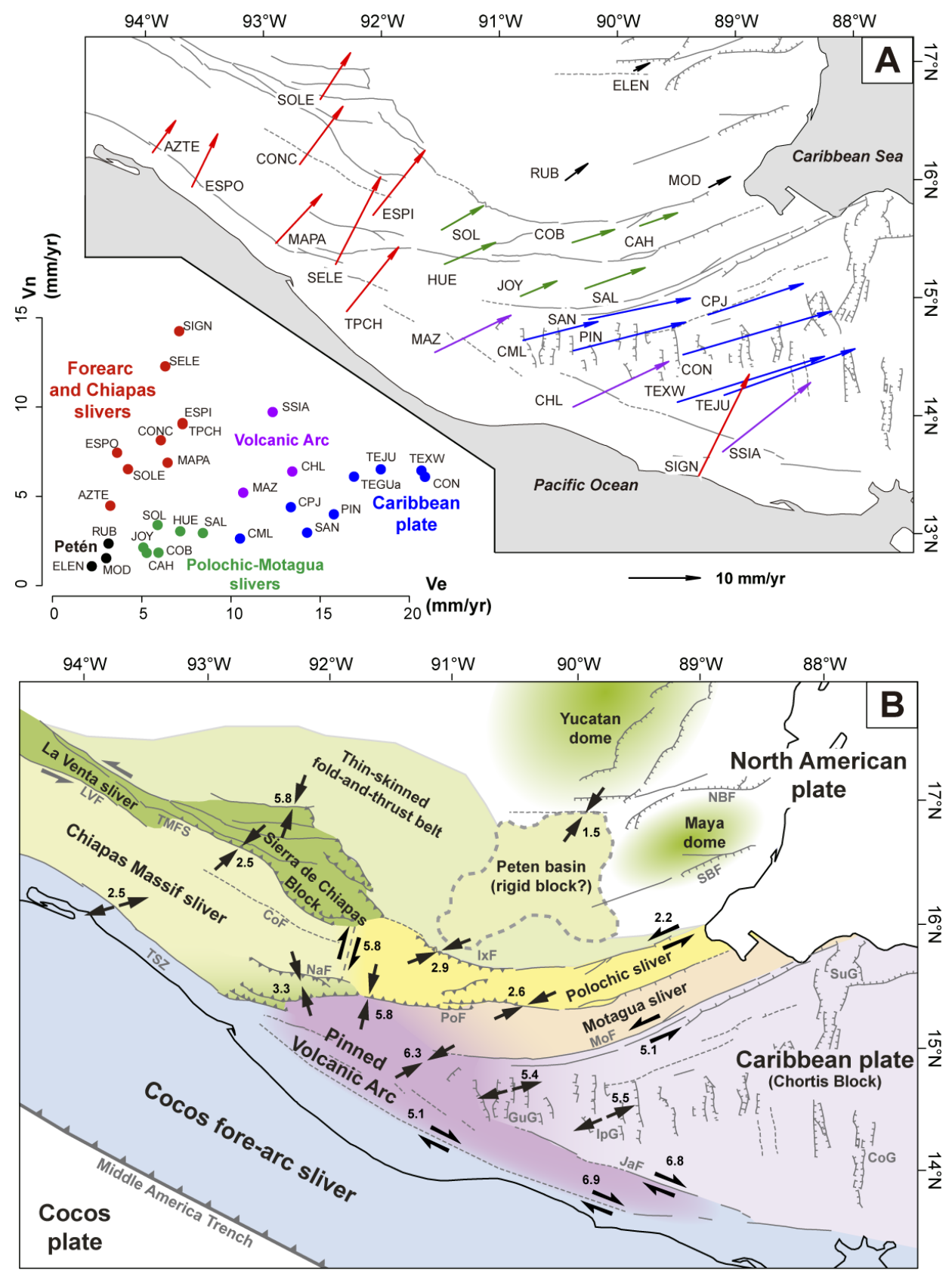

Figure 18. Proposed limits of tectonic slivers forming the plate boundary. (a) GPS velocities with respect to the fixed North American Plate (Franco et al., 2012). Colors emphasize vectors with similar azimuths and velocities. The diagram of northern and eastern components (bottom left corner) allows for motions between paired GPS stations to be deduced. (b) Main tectonic blocks defined using known major faults (Fig. 2), our geomorphic maps (Figs. 7 and 8) and published GPS data (Fig. 18a) and seismicity (Fig. 3a). Black arrows show the motion along block boundaries deduced from paired GPS stations (values are in $\mathrm{mm} \mathrm{yr}^{-1}$ ). See Fig. 2 for faults abbreviations.

However, the differential motion between GPS stations ESPO and CONC (Fig. 18) suggests that the fault zone currently accommodates a $\sim 2.5 \mathrm{~mm} \mathrm{yr}^{-1}$ ENE extension. Our geomorphic analyses suggest that the landscapes of the Chiapas Massif are mostly in steady state. However, the southern tip of the massif displays evidence of topographic rejuvenation. River profiles crossing the northern segment of the
Tonalá shear zone (profile 6 in Fig. 12) show no major perturbations and thus indicate an equilibrium between erosion and uplift. Towards the SE, river profiles display a gentle knickzone associated with a $50-150 \mathrm{~m}$ base-level fall (profile 15 in Fig. 12). In the same area, Authemayou et al. (2011) observed that alluvial fans across the fault zone are affected by vertical offsets ranging between 15 and $60 \mathrm{~m}$. The base-level 
drop we observe in river profiles is thus related to a gentle uplift along the central portion of the Tonalá shear zone. Finally, river profiles along the southern termination of the fault zone (profile 21 in Fig. 12) exhibit prominent knickpoints and convex segments, which indicate a major disequilibrium. The $k_{\mathrm{sn}}$ values increase southward along the Tonalá shear zone but in fact all the areas located between the Polochic Fault and the Necta Fault display high $k_{\text {sn }}$ values (Fig. 15). Under constant climate and lithologies, the steepness index $\left(k_{\mathrm{sn}}\right)$ correlates with uplift rates (e.g., Kirby and Whipple, 2001; Wobus et al., 2006; Kirby and Whipple, 2012). We thus suspect higher uplift rates along the southern border of the Chiapas Massif (north of the Polochic Fault and south of the Necta Fault). The Necta Fault separates the northern domain, where the topography is almost in steady state, from the southern domain, where landscapes are being rejuvenated due to an increase in uplift rates. We propose to define a rigid block (referred to as the "Chiapas Massif sliver" in Fig. 18b) delimited by the Tonala shear zone to the west, by the La Venta and Tuxtla faults to the east and by the Necta Fault to the south. The Tonalá shear zone seems to accommodate a $2.5 \mathrm{~mm} \mathrm{yr}^{-1}$ extension, while the Tuxtla Fault instead accommodates a $2.5 \mathrm{~mm} \mathrm{yr}^{-1}$ shortening (Fig. 18b).

The northern tip of the Central American volcanic arc forms an uplifted plateau with a mean elevation of $\sim 3000 \mathrm{~m}$. The drainage network developed prominent knickzones as it responded to high-amplitude base-level changes (Figs. 11 and 12 and $k_{\mathrm{sn}}$ map in Fig. 15). The differential motion between GPS stations TPCH and SOL (Fig. 18) indicates a $\sim 5.8 \mathrm{~mm} \mathrm{yr}^{-1} \mathrm{NNE}$ shortening between the Pacific coastal plain and the Sierra de los Cuchumatanes. We also noted that the motion of GPS stations located along the volcanic arc (MAZ, CHL and SSIA in Fig. 18) is intermediate between the Cocos forearc sliver and the Caribbean Plate. From the motion of these GPS stations we infer a dextral fault zone bounding the southern edge of the volcanic arc. We suspect that the volcanic arc acts as a tectonic sliver which accommodates a significant part of the motion between the Cocos forearc sliver and the overriding plates. East of the graben of Guatemala City, the sliver is possibly delimited by two right-lateral fault zones which accommodate each half of the motion $\left(\sim 13 \mathrm{~mm} \mathrm{yr}^{-1}\right)$ between the Cocos forearc sliver and the Caribbean Plate. West of the graben of Guatemala City, the volcanic arc sliver is pinned between the Cocos forearc sliver to the SW, the Polochic sliver to the NE and the Chiapas Massif to the north (Fig. 18b). Though a $6.3 \mathrm{~mm} \mathrm{yr}^{-1}$ shortening is expected between GPS stations MAZ and JOY, we could not find a clear limit between this volcanic arc sliver and the Motagua sliver.

Within the Sierra Madre de Chiapas orogenic belt, most of the present-day seismicity (Fig. 3b) is located along the strike-slip faults of Chiapas, which delimitate the La Venta block (profile 1 in Fig. 5) and the northern part of the Sierra de Chiapas, and along the inner part of the Chiapas fold-and-thrust belt, east of the Sierra de Chiapas and
Comitán High uplifted domain. In addition, two historical events were documented within the Central valley of Chiapas: the 14 March 1591 (García-Acosta and Suárez-Reynoso, 1996; Peraldo and Montero, 1999; Guzmán-Speziale, 2010) and the 23 September 1902 (Böse, 1903; Figueroa, 1973) earthquakes. Historical earthquakes of this area were attributed to either the Concordia (Guzmán-Speziale, 2010) or the Tuxtla (Andreani et al., 2008a) Fault. The differential motion between GPS stations CONC and SOLE suggests $\mathrm{a} \sim 2.5 \mathrm{~mm} \mathrm{yr}^{-1}$ NE-trending compression which is perpendicular to the azimuth of mapped faults. Our geomorphic data suggest that the Tuxtla Fault is more likely to have produced these earthquakes. The Concordia fault trace is not associated with any major fault scarps and rivers display a rather low degree of perturbation. By contrast the Tuxtla fault scarp displays a very young and prominent morphology (high hypsometry and low surface roughness) and the drainage network responded to a significant base-level fall ( $>500 \mathrm{~m}$, profiles 1-3 in Fig. 14). Moreover, major topographic uplift took place east of the Tuxtla Fault (Comitán High and the Sierra de Chiapas), where the elevation of relict landscapes is between 1600 and $2400 \mathrm{~m}$.

Finally, our results bring new evidence for topographic uplift within the Maya Mountains. Most of the Maya Mountains consist of an uplifted low-relief landscape. The isobase surface from rivers is more elevated in the southern part of the Maya Mountains, thus suggesting stronger uplift in the south. The analysis of rivers longitudinal profiles is consistent with this interpretation. The reconstruction of profiles made using the upper reaches (associated with the low relict surface) show that rivers faced a $\sim 500 \mathrm{~m}$ base-level fall in the south (profiles 6, 4 and 8 in Fig. 16). Northern rivers (profiles 1-3 in Fig. 16) were affected by a lower (ca. $300 \mathrm{~m}$ ) base-level change. The topographic profile across the Maya Mountains and the Yucatán Peninsula (Fig. 6) is consistent with a geometry of blocks tilted towards the NW along NE-trending normal faults.

\subsection{Proposed model of the plate boundary}

The proposed model for the North American-CaribbeanCocos plate boundary is displayed in Fig. 19. This model incorporate main ideas from previous works. East of $91^{\circ} \mathrm{W}$ the dynamic of the plate boundary is guided by the eastward escape of the Caribbean Plate. This motion results in sinistral shear along the Polochic and Motagua slivers, dextral shear along the Jalpatagua Fault and extension mainly concentrated along the grabens of Guatemala City and Ipala (Figs. 18b and 19; e.g., Lyon-Caen et al., 2006; Authemayou et al., 2011). Recent models of the triple junction also agree on the fact that both the North American and the Caribbean Plate are limited by a rigid forearc sliver to the west (Turner et al., 2007; Phipps-Morgan et al., 2008; Authemayou et al., 2011). The eastward escape of the Caribbean Plate results 


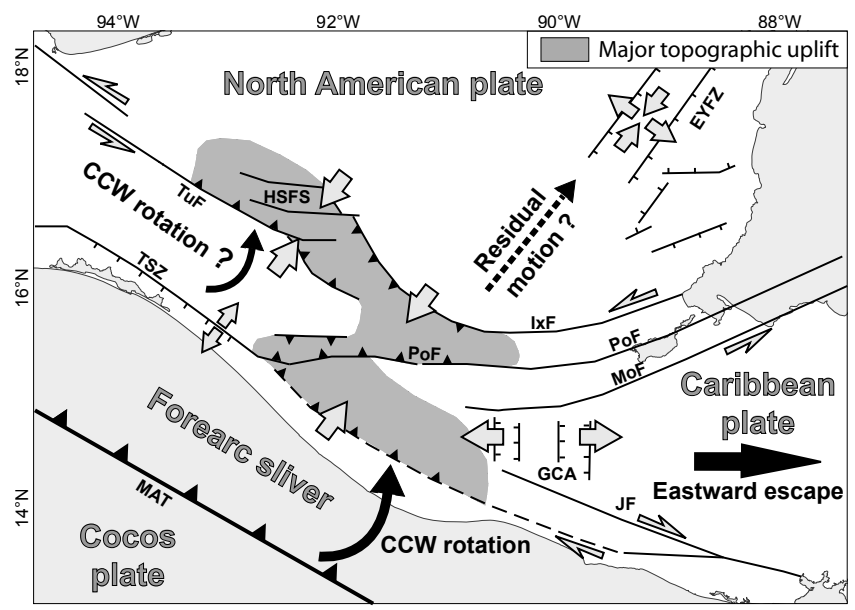

Figure 19. Proposed model for the North American-CaribbeanCocos plate boundary in northern Central America. Abbreviations: EYFZ - eastern Yucatán fault zone; GCA - grabens of Central America; HSFS - High Sierra fault system; IxF - Ixcán Fault; JaF Jalpatagua Fault; MAT - Middle America Trench; MoF - Motagua Fault; PoF - Polochic Fault; TSZ - Tonalá shear zone; TuF - Tuxtla Fault.

in a counterclockwise rotation of the rigid forearc sliver (Phipps-Morgan et al., 2008; Authemayou et al., 2011).

The interactions between the forearc sliver and the North American Plate were summarized as distributed compression north of the Polochic Fault (Guzmán-Speziale and MenesesRocha, 2000; Andreani et al., 2008a; Witt et al., 2012b). Our interpretation, based on the characterization of elevated relict landscapes and published geophysical data, is that the compression between the forearc sliver and the North American is mainly absorbed at the boundary of small tectonic blocks which act as "buffers" (Fig. 18b). As a result, significant topographic uplift occurred along two narrow domains. The first one encompasses the Sierra de Chiapas and the western tip of the Polochic sliver (Sierra de los Cuchumatanes) and the second one corresponds to the northern tip of the volcanic arc (Fig. 19).

Within the Sierra Madre de Chiapas, the distribution of highest relict landscapes $(>1500 \mathrm{~m})$ indicates that significant topographic uplift occurred between the Tuxtla Fault and reverse structures located east of the Sierra de Chiapas and Comitán High. Our results and those of Authemayou et al. (2011) also provide evidence for vertical motions along the Tonalá shear zone. There are evidence for a Miocene sinistral motions along the Tonalá shear zone and for the Tuxtla and Malpaso faults (Guzmán-Speziale and Meneses-Rocha, 2000; Witt et al., 2012b; Molina-Garza et al., 2015). However, the GPS data suggest a presentday $\sim 2.5 \mathrm{~mm} \mathrm{yr}^{-1}$ extension along the Tonalá shear zone and a similar amount of compression along the Tuxtla Fault (Fig. 18). These two opposite movements are possibly related to a counterclockwise rotation of the Chiapas Massif
(Fig. 19) following a reorganization of the subduction interface. The middle Miocene to present evolution of the Sierra Madre de Chiapas is associated with an inland migration of the Chiapanecan volcanic arc (Damon and Montesinos, 1978) resulting from a flattening of the subduction beneath southern Mexico (Manea and Manea, 2006; Manea et al., 2013). This flattening would have resulted in higher coupling along the subduction interface, as suggested by Franco et al. (2012). As a result, the areas west of the Tuxtla Fault (which is located along most of the present-day volcanic centers) became partially incorporated into the forearc domain. This would explain why significant Plio-Quaternary topographic growth $(>1000 \mathrm{~m})$ mainly occurred east of the Tuxtla Fault rather than along the Tonalá shear zone.

The compression between the rotating forearc sliver and the North American Plate resulted in topographic uplift along the Sierra de los Cuchumatanes and the northern tip of the Central American volcanic arc (Authemayou et al., 2011, this study). In existing models, the westernmost corner of the Caribbean Plate is stretched along NE-trending normal faults and the counterclockwise rotation of the forearc sliver is associated with a zipping (i.e., a suture zone) between the inferred prolongation of the Jalpatagua and Motagua faults (Authemayou et al., 2011; Franco et al., 2012). However, a suture zone between the Jalpatagua and Motagua faults may not fully explain why the volcanic arc is uplifted, mainly because most of the elevated volcanic arc plateau is located west of the area where both faults would be zipped. To explain the atypical motions of GPS stations along the volcanic arc and the topographic elevation of the plateau (MAZ, CHL and SSIA in Fig. 18a) we infer a fault zone bounding the western edge of the volcanic arc (Figs. 18 and 19) and along which the volcanic arc plateau is uplifted. The indentation of the volcanic arc to the north possibly resulted in the topographic rejuvenation of the southern Chiapas Massif as well.

The interaction between the Maya Mountains and the rest of the plate boundary is unclear. Our hypothesis is that a part of the compression associated with the uplift of the volcanic arc and the Sierra de Cuchumatanes is transmitted towards the Yucatán platform and the Maya Mountains through the Petén Basin. The Petén Basin is a surprisingly flat and low area with a mean elevation of $\sim 150 \mathrm{~m}$ (swath profile 4 in Fig. 6). It contrasts greatly with the topography of the Sierra de los Cuchumatanes, which instead culminates at $\sim 3800 \mathrm{~m}$, and the scarp of the Ixcán Fault is almost $1000 \mathrm{~m}$ high (profile 4 in Fig. 6). We suspect that the Petén Basin is underlain by a rigid basement which acts as a rigid crustal block. The extreme topography of the Sierra de los Cuchumatanes can be explained by an abutment along this more rigid block. A rigid Petén block would also explain how a residual part of the motion along the triple junction may have been transmitted to the Yucatán Peninsula and Maya Mountains. This residual motion may have reactivated NE-trending faults inherited from the Eocene opening of the Yucatán Basin (Rosencrantz, 1990; Leroy et al., 2000). 


\section{Conclusions}

We demonstrate that a geomorphic analysis allows for classification of zones of similar relief patterns that we assume witnessed different tectonic and erosive histories. Using DEMbased geomorphic indices, we examined the topography of the Sierra Madre de Chiapas and the Maya Mountains. We used topographic profiles and morphometric maps in order to understand the spatial distribution of landscapes, and we also analyzed in detail the disequilibrium of drainage network in order to map potential vertical displacements. Finally, we combined our results with existing GPS and seismological data in order to better understand the interactions between tectonics and landscapes within the highly diffuse North American-Caribbean-Cocos plate boundary.

Our analysis indicates that the topography of the Sierra Madre de Chiapas and the Maya Mountains is in a transient stage. Topographic profiles and morphometric maps highlight elevated relict landscapes which are characterized by a low-amplitude relief. These relict landscapes are surrounded by areas being actively eroded. River longitudinal profiles display knickzones which separate an upper reach associated with these relict landscapes from lower and steeper segments along which channels adjust to new base-level conditions. The relict landscapes from the Sierra Madre de Chiapas and the Maya Mountains probably evolved from an initially low topography which was then uplifted and fragmented by tectonics. This initial low-relief topography is possibly a northern equivalent of the so-called "Mayan paleosurface" (Authemayou et al., 2011; Brocard et al., 2011) which covered most of the Polochic-Motagua sliver and formed at low elevation during the middle Miocene (between 13 and $7 \mathrm{Ma}$ ).

East of $91^{\circ} \mathrm{W}$ the dynamic of the triple junction is mainly related to the eastward escape of the Caribbean Plate (LyonCaen et al., 2006; Authemayou et al., 2011), which resulted in sinistral shear along the Polochic and Motagua slivers, dextral shear along the Jalpatagua Fault and extension mainly concentrated along the grabens of Guatemala City and Ipala. West of $91^{\circ} \mathrm{W}$ we mainly observe compression resulting from the counterclockwise rotation of the Cocos forearc sliver. Within the Sierra Madre de Chiapas, this compression resulted in a major topographic uplift east of the Tuxtla and La Venta faults (Sierra de Chiapas and La Venta slivers in Fig. 18b). Within the Sierra de Chiapas and Comitán High, relict landscapes are found at elevations between 1600 and $2400 \mathrm{~m}$. The areas between the Tuxtla and La Venta faults to the east and the Tonalá shear zone to the west were also uplifted but to a lesser extent (400-600 m). Major uplift is also observed along the western tip of the Polochic sliver (Sierra de los Cuchumatanes) and the northern tip of the volcanic arc. Using GPS data and morphotectonic analyses, we propose that the northern tip of the Central American volcanic arc is part of a tectonic sliver which has been pinned between the Cocos forearc sliver and the North American Plate (Fig. 18b). Our study also brings new evidence for a 250
$500 \mathrm{~m}$ topographic uplift within the Maya Mountains. Our hypothesis is that a residual part of the compression along the plate boundary is transmitted towards the Yucatán platform and the Maya Mountains through a rigid basement underlying the Petén Basin.

Acknowledgements. The authors thank John Armitage, José Vicente Pérez-Peña and Giulia Sofia for their constructive reviews and comments.

Edited by: G. Sofia

\section{References}

Albani, M., Klinkerberg, B., Andison, D., and Kimmis, J. P.: The choice of window size in approximating topographic surfaces from Digital Elevation Models, Int. J. Geogr. Inf. Sci., 18, 577593, 2004.

Ambraseys, N. N. and Adams, R. D.: Large-magnitude Central American earthquakes, 1898-1994, Geophys. J. Int., 127, 665692, 1996.

Andreani, L., Le Pichon, X., Rangin, C., and Martínez-Reyes, J.: The southern Mexico block: main boundaries and new estimation for its quaternary motion, B. Soc. Geol. Fr., 179, 209-223, 2008a.

Andreani, L., Rangin, C., Martínez-Reyes, J., Le Roy, C., ArandaGarcía, M., Le Pichon, X., and Peterson-Rodriguez, R.: The Neogene Veracruz fault: evidences for left-lateral slip along the southern Mexico block, B. Soc. Geol. Fr., 179, 195-208, 2008 b.

Andreani, L., Stanek, K. P., Gloaguen, R., Krentz, O., and Domínguez-González, L.: DEM-based analysis of interactions between tectonics and landscapes in the Ore Mountains and Eger Rift (East Germany and NW Czech Republic), Remote Sensing, 6, 7971-8001, doi:10.3390/rs6097971, 2014.

Authemayou, C., Brocard, G., Teyssier, C., Simon-Labric, T., Guttiérrez, A., Chiquín, E. N., and Morán, S.: The CaribbeanNorth America-Cocos triple junction and the dynamics of the Polochic-Motagua fault systems: pull-up and zipper models, Tectonics, 30, 1-23, doi:10.1029/2010TC002814, 2011.

Authemayou, C., Brocard, G., Teyssier, C., Suski, B., Cosenza, B., Morán-Ical, S., González-Véliz, C. W., AguilarHengstenberg, M. A., and Holliger, K.: Quaternary seismotectonic activity of the Polochic Fault, Guatemala, J. Geophys. Res., 117, B07403, doi:10.1029/2012JB009444, 2012.

Bateson, J. H. and Hall, I. S. H.: The geology of the Maya Mountains, Belize, Institute of Geological Sciences (Great Britain), Natural Environment Research Council, Overseas Memoir, 3, 144, 1977.

Bauer-Gottwein, P., Gondwe, B. R. N., Charvet, G., Marín, L. E., Rebolledo-Vieyra, M., and Merediz-Alonso, G.: Review: the Yucatán Peninsula karst aquifer, Mexico, Hydrogeol. J., 19, 507524, 2011.

Bookhagen, B.: High resolution spatiotemporal distribution of rainfall seasonality and extreme events based on a 12-year TRMM time series, available at: http://www.geog.ucsb.edu/ bodo/TRMM/\#tif (last access: 20 November 2015), 2009.

Böse, E.: Informe sobre los temblores de Zanatepec a fines de septiembre de 1902 y sobre el estado actual del volcán de Tacaná, 
vol. 1, Parergones del Instituto Geológico, Imprenta y Fototipía de la Secretaría de Fomento, Ciudad de México, México, 1903.

Brocard, G., Teyssier, C., Dunlap, W. J., Authemayou, C., SimonLabric, T., Cacao-Chiquín, E. N., Gutiérrez-Orrego, A., and Morán-Ical, S.: Reorganization of a deeply incised drainage: role of deformation, sedimentation and groundwater flow, Basin Res., 23, 631-651, doi:10.1111/j.1365-2117.2011.00510.x, 2011.

Burbank, D. W. and Anderson, R. S.: Tectonic Geomorphology, Blackwell Science, Cambridge, 2001.

Burkart, B.: Offset across the Polochic fault of Guatemala and Chiapas, Mexico, Geology, 6, 328-332, 1978.

Burkart, B.: Neogene North American-Caribbean plate boundary across Northern Central America: offset along the Polochic fault, Tectonophysics, 99, 251-270, 1983.

Burrough, P. A. and Mcdonell, R.: Principles of Geographical Information Systems, Oxford University Press, New York, US, 1998.

Chen, Y.-C., Sung, Q., and Cheng, K.-Y.: Along-strike variations of morphotectonic features in the Western Foothills of Taiwan: tectonic implications based on stream-gradient and hypsometric analysis, Geomorphology, 56, 109-137, 2003.

Clark, M. K., Maheo, G., Saleeby, J., and Farley, K. A.: The nonequilibrium landscape of the southern Sierra Nevada, California, GSA Today, 15, 4-10, 2005.

Correa-Mora, F., DeMets, C., Alvarado, D., Turner, H. L., Mattioli, G., Hernandez, D., Pullinger, C., Rodriguez, M., and Tenorio, C.: GPS-derived coupling estimates for the Central America subduction zone and volcanic arc faults: El Salvador, Honduras and Nicaragua, Geophys. J. Int., 179, 1279-1291, 2009.

Damon, P. E. and Montesinos, E.: Late Cenozoic volcanism and metallogenesis over an active Benioff zone in Chiapas, Mexico, Arizona Geological Society Digest, X1, 155-168, 1978.

Deaton, B. C. and Burkart, B.: Time of sinistral slip along the Polochic fault of Guatemala, Tectonophysics, 102, 297-313, 1984.

DeMets, C.: A new estimate for present-day Cocos-Caribbean plate motion: implications for slip along the Central American volcanic arc, Geophys. Res. Lett., 28, 4043-4046, 2001.

Domínguez-González, L., Andreani, L., Stanek, K. P., and Gloaguen, R.: Geomorpho-tectonic evolution of the Jamaican restraining bend, Geomorphology, 228, 320-334, 2015.

Dury, G. H.: Map Interpretation, Sir Isaac Pitman \& Sons, Ltd, London, UK, 1952.

Fairfield, J. and Leymarie, P.: Drainage networks from grid digital elevation models, Water Resour. Res., 27, 709-717, 1991.

Ferrater, M., Booth-Rea, G., Pérez-Peña, J. V., Azañón, J. M., Giaconia, F., and Masana, E.: From extension to transpression: Quaternary reorganization of an extensional-related drainage network by the Alhama de Murcia strike-slip fault (eastern Betics), Tectonophysics, 663, 33-47, doi:10.1016/j.tecto.2015.06.011, 2015.

Figueroa, J.: Sismicidad en Chiapas, Instituto de Ingeniería de la UNAM, DF, Ciudad de México, México, 1973.

Filosofov, V. P.: Brief Guide to Morphometric Methods in Search of Tectonic Structures, Saratov University Publishing House, Saratov, Russia, 1960 (in Russian).

Flint, J. J.: Stream gradient as a function of order, magnitude and discharge, Water Resour. Res., 10, 969-973, 1974.

Font, M., Amorese, D., and Lagarde, J. L.: DEM and GIS analysis of the stream gradient index to evaluate effects of tectonics: the
Normandy intraplate area (NW France), Geomorphology, 119, 172-180, 2010.

Franco, A., Lasserre, C., Lyon-Caen, H., Kostoglodov, V., Molina, E., Guzmán-Speziale, M., Monterosso, D., Robles, V., Figueroa, C., Amaya, W., Barrier, E., Chiquin, L., Moran, S., Flores, O., Romero, J., Santiago, J. A., Manea, M., and Manea, V. C.: Fault kinematics in northern Central America and coupling along the subduction interface of the Cocos Plate, from GPS data in Chiapas (Mexico), Guatemala and El Salvador, Geophys. J. Int., 189, 1223-1236, 2012.

Fuchs, M. C., Gloaguen, R., Merchel, S., Pohl, E., Sulaymonova, V. A., Andermann, C., and Rugel, G.: Denudation rates across the Pamir based on ${ }^{10} \mathrm{Be}$ concentrations in fluvial sediments: dominance of topographic over climatic factors, Earth Surf. Dyn., 3, 423-439, 2015.

Gallen, S. F., Wegmann, K. W., and Bohnenstiehl, D. R.: Miocene rejuvenation of topographic relief in the southern Appalachians, GSA Today, 23, 4-10, doi:10.1130/GSATG163A.1, 2013.

García-Acosta, V. and Suárez-Reynoso, G.: Los sismos en la historia de México. Tomo I, Fondo de Cultura Económica, Ciudad de México, México, 1996.

Garrity, C. and Soller, D.: Database of the Geologic Map of North America; adapted from the map by: Reed Jr., J. C. et al. (2005), US Geological Survey Data Series 424, available at: http://pubs. usgs.gov/ds/424/ (last access: 22 November 2015), 2009.

Giletycz, S., Loget, N., Chang, C. P., and Mouthereau, F.: Transient fluvial landscape and preservation of low-relief terrains in an emerging orogen: example from Hengchun Peninsula, Taiwan, Geomorphology, 231, 169-181, 2015.

Godard, V., Bourlès, D. L., Spinabella, F., Burbank, D. W., Bookhagen, B., Burch Fisher, G., Moulin, A., and Léanni, L.: Dominance of tectonics over climate in Himalayan denudation, Geology, 42, 243-246, 2014.

Golts, S. and Rosenthal, E.: A morphotectonic map of the northern Arava in Israel, derived from isobase lines, Geomorphology, 7, 305-315, 1993.

Gordon, M. and Muehlberger, W. R.: Rotation of the Chortis block causes dextral slip on the Guayapé fault, Tectonics, 13, 858-872, 1994.

Grohmann, C. H.: Morphometric analysis in Geographic Information Systems: applications of free software GRASS and R, Comput. Geosci., 30, 1055-1067, 2004.

Grohmann, C. H., Riccomini, C., and Alves, F. M.: SRTM-based morphotectonic analysis of the Pocos de Caldas Alkaline Massif, southeastern Brazil, Comput. Geosci., 33, 10-19, 2007.

Grohmann, C. H., Smith, M. J., and Riccomini, C.: Surface roughness of topography: a multi-scale analysis of landform elements in Midland Valley, Scotland, Proceedings of Geomorphometry 2009, Zurich, Switzerland, 31 August-2 September 2009, 140 148, 2009.

Grohmann, C. H., Riccomini, C., and Chamani, M. A. C.: Regional scale analysis of landform configuration with baselevel (isobase) maps, Hydrol. Earth Syst. Sci., 15, 1493-1504, doi:10.5194/hess-15-1493-2011, 2011.

Guzmán-Speziale, M.: Active seismic deformation in the grabens of northern Central America and its relationship to the relative motion of the North America-Caribbean plate boundary, Tectonophysics, 337, 39-51, 2001. 
Guzmán-Speziale, M.: Beyond the Motagua and Polochic faults: active strike-slip faulting along the western North AmericaCaribbean plate boundary zone, Tectonophysics, 496, 17-27, 2010.

Guzmán-Speziale, M. and Meneses-Rocha, J. J.: The North America-Caribbean plate boundary west of the MotaguaPolochic fault system: a fault jog in southeastern Mexico, J. S. Am. Earth Sci., 13, 459-468, 2000.

Guzmán-Speziale, M., Pennington, W. D., and Matumoto, T.: The triple junction of the North America, Cocos, and Caribbean plates: seismicity and tectonics, Tectonics, 8, 981-997, 1989.

Hack, J. T.: Studies of longitudinal stream profiles in Virginia and Maryland, US Geological Survey Professional Paper, 294, 4597, 1957.

Hack, J. T.: Interpretation of erosional topography in humid temperate regions, Am. J. Sci., 258, 80-97, 1960.

Hergarten, S., Robl, J., and Stüwe, K.: Extracting topographic swath profiles across curved geomorphic features, Earth Surf. Dynam., 2, 97-104, doi:10.5194/esurf-2-97-2014, 2014.

Hobson, R. D.: Surface roughness in topography: quantitative approach, in: Spatial analysis in geomorphology, edited by: Chorley, R. J., Methuer, London, UK, 225-245, 1972.

Isacks, B. L.: Long term land surface processes: erosion, tectonics and climate history in mountain belts, in: TERRA-1: Understanding the Terrestrial Environment, edited by: Mather, P. M., Taylor and Francis, London, UK, 21-36, 1992.

Jarvis, A., Reuter, H. I., Nelson, A., and Guevara, E.: Hole-filled seamless SRTM data V4, International Centre for Tropical Agriculture (CIAT), available at: http://srtm.csi.cgiar.org (last access: 25 November 2014), 2008.

Jones, R.: Algorithms for using a DEM for mapping catchment areas of stream sediment samples, Comput. Geosci., 28, 10511060, 2002.

Keller, E. A. and Pinter, N.: Active tectonics: earthquakes, uplift, and landscape, Prentice Hall, Englewood Cliffs, N.J., 1996.

Kesler, S. E., Kienle, C. F., and Bateson, J. H.: Tectonic significance of intrusive rocks in the Maya Mountains, British Honduras, Geol. Soc. Am. Bull., 85, 549-552, 1974.

Kirby, E. and Whipple, K. X.: Quantifying differential rock-uplift rates via stream profile analysis, Geology, 29, 415-418, 2001.

Kirby, E. and Whipple, K. X.: Expression of active tectonics in erosional landscapes, J. Struct. Geol., 44, 54-75, 2012.

Lara, M. E.: Divergent wrench faulting in the Belize southern lagoon: implications for tertiary Caribbean plate movements and Quaternary reef distribution, AAPG Bull., 77, 1041-1063, 1993.

Legrain, N., Stüwe, K., and Wölfler, A.: Incised relict landscapes in the eastern Alps, Geomorphology, 221, 124-138, 2014.

Leroy, S., Mauffret, A., Patriat, P., and Mercier de Lépinay, B.: An alternative interpretation of the Cayman trough evolution from a reidentification of magnetic anomalies, Geophys. J. Int., 141, 539-557, 2000.

Lesser, J. M. and Weidie, A. E.: Region 25, Yucatan Peninsula, in: Hydrogeology, edited by: Back, W., Rosenhein, J. S., and Seaber, P. R., Geological Society of America, Boulder, Colorado, 237-242, 1988.

Lyon-Caen, H., Barrier, E., Lasserre, C., Franco, A., Arzu, I., Chiquin, L., Chiquin, M., Duquesnoy, T., Flores, O., Galicia, O., Luna, J., Molina, E., Porras, O., Requena, J., Robles, V., Romero, J., and Wolf, R.: Kinematics of the North American-
Caribbean-Cocos plates in Central America from new GPS measurements across the Polochic-Motagua fault system, Geophys. Res. Lett., 33, L19309, doi:10.1029/2006GL027694, 2006.

Mahmood, S. A. and Gloaguen, R.: Appraisal of active tectonics in Hindu Kush: Insights from DEM derived geomorphic indices and drainage analysis, Geosci. Front., 3, 407-428, doi:10.1016/j.gsf.2011.12.002, 2012.

Malfait, B. T. and Dinkelman, M. G.: Circum-Caribbean tectonic and igneous activity and evolution of the Caribbean plate, Geol. Soc. Am. Bull., 83, 251-272, 1972.

Manea, V. C. and Manea, M.: Origin of the modern Chiapanecan volcanic arc in southern Mexico inferred from thermal models, Geol. S. Am. S., 411, 27-38, 2006.

Manea, V. C., Manea, M., and Ferrari, L.: A geodynamical perspective on the subduction of Cocos and Rivera plates beneath Mexico and Central America, Tectonophysics, 609, 56-81, 2013.

Mann, P. and Burke, K.: Cenozoic rift formation in the Northern Caribbean, Geology, 12, 732-736, 1984.

Masek, J. G., Isacks, B. L., Gubbels, T. L., and Fielding, E. J.: Erosion and tectonics at the margins of continental plateaus, J. Geophys. Res., 99, 13941-13956, doi:10.1029/94JB00461, 1994.

Mather, A. E.: Adjustment of a drainage network to capture induced base-level change, Geomorphology, 34, 271-289, 2000.

Matmon, A., Bierman, P., Larsen, J., Southworth, S., Pavich, M., and Caffee, M.: Temporally and spatially uniform rates of erosion in the southern Appalachian Great Smoky Mountains, Geology, 31, 155-158, 2003.

Meneses-Rocha, J. J.: Tectonic evolution of the Ixtapa Graben, an example of a strike-slip basin of southeastern Mexico: implications for regional petroleum systems, in: The Western Gulf of Mexico Basin: Tectonics, Sedimentary Basins and Petroleum Systems, AAPG Memoir 75, edited by: Bartolini, C., Buffler, R. T., and Cantú-Chapa, A., The American Association of Petroleum Geologists, Tulsa, Oklahoma, USA, 183-216, 2001.

Molina-Garza, R. S., Geissman, J. W., Wawrzyniec, T. F., Peña Alonso, T. A., Iriondo, A., Weber, B., and Aranda-Gómez, J.: Geology of the coastal Chiapas (Mexico) Miocene plutons and the Tonala shear zone; syntectonic emplacement and rapid exhumation during sinistral transpression, Lithosphere, 7, 257-274, 2015.

Montgomery, D. R. and Foufoula-Georgiou, E.: Channel network source representation using digital elevation models, Water Resour. Res., 29, 3925-3934, 1993.

O'Callaghan, J. F. and Mark, D. M.: The extraction of drainage networks from digital elevation data, Comput. Vision Graph., 28, 323-344, 1984.

Pazzaglia, F. J.: Landscape evolution models, in: The Quaternary Period in the United States, edited by: Gillespie, A., Porter, S., and Atwater, B., Elsevier Science Ltd., Oxford, UK, 247-274, 2003.

Pedrera, A., Pérez-Peña, J. V., Galindo-Zaldívar, J., Azañón, J. M., and Azor, A.: Testing the sensitivity of geomorphic indices in areas of low-rate active folding (eastern Betic Cordillera, Spain), Geomorphology, 105, 218-231, 2009.

Peraldo, G. and Montero, W.: Sismología Histórica de América Central, Instituto Panamericano de Geografía e Historia, Ciudad de México, México, 1999.

Pérez-Peña, J. V., Azañón, J. M., Booth-Rea, G., Azor, A., and Delgado, J.: Differentiating geology and tectonics using a spatial au- 
tocorrelation technique for the hypsometric integral, J. Geophys. Res.-Earth, 114, F02018, doi:10.1029/2008JF001092, 2009.

Pérez-Peña, J. V., Azañón, J. M., Azor, A., Booth-Rea, G., Galve, J. P., Roldán, F. J., Mancilla, F., Giaconia, F., Morales, J., and Al-Awabdeh, M.: Quaternary landscape evolution driven by slabpull mechanisms in the Granada Basin (Central Betics), Tectonophysics, 663, 33-47, doi:10.1016/j.tecto.2015.07.035, 2015.

Phipps-Morgan, J., Ranero, C. R., and Vannucchi, P.: Intra-arc extension in Central America: links between plate motions, tectonics, volcanism, and geochemistry, Earth Planet. Sc. Lett., 272, 365-371, 2008

Pike, R. J. and Wilson, S. E.: Elevation relief ratio, hypsometric integral, and geomorphic area-altitude analysis, Geol. Soc. Am. Bull., 82, 1079-1084, 1971.

Plafker, G.: Tectonic aspects of the Guatemalan earthquake of 4 February 1976, Science, 193, 1201-1208, 1976.

Purdy, E. G., Gischler, E., and Lomando, A. J.: The Belize margin revisited. 2. Origin of Holocene antecedent topography, Int. J. Earth Sci., 92, 552-572, 2003.

Rao, R. P. and Ramanathan, R.: Belize $1988-89$ petroleum activity keyed to prices, Oil and Gas Journal, 86, 81-91, 1988.

Ratschbacher, L., Franz, L., Min, M., Bachmann, R., Martens, U., Stanek, K., Stübner, K., Nelson, B. K., Herrmann, U., Weber, B., López-Martínez, M., Jonckheere, R., Sperner, B., Tichomirowa, M., Mcwilliams, M. O., Gordon, M., Meschede, M., and Bock, P.: The North American-Caribbean Plate boundary in Mexico-Guatemala-Honduras, Geological Society, London, UK, Special Publications, 328, 219-293, 2009.

Reinhardt, L. J., Bishop, P., Hoey, T. B., Dempster, T. J., and Sanderson, D. C. W.: Quantification of the transient response to base-level fall in a small mountain catchment: Sierra Nevada, southern Spain, J. Geophys. Res., 112, F03S05, doi:10.1029/2006JF000524, 2007.

Rodriguez, M., DeMets, C., Rogers, R., Tenorio, C., and Hernandez, D.: A GPS and modelling study of deformation in northern Central America, Geophys. J. Int., 178, 1733-1754, 2009.

Rogers, R. D., Kárason, H., and van der Hilst, R. D.: Epeirogenic uplift above a detached slab in northern Central America, Geology, 30, 1031-1034, 2002.

Rosencrantz, E.: Structure and tectonics of the Yucatan basin, Caribbean Sea, as determined from seismic-reflection studies, Tectonics, 9, 1037-1059, 1990.

Sánchez-Barreda, L. A.: Geologic evolution of the continental margin of the Gulf of Tehuantepec in southern Mexico, PhD thesis, University of Texas, Austin, Texas, 1981.

Schoenbohm, L. M., Whipple, K. X., Burchfiel, B. C., and Chen, L.: Geomorphic constraints on surface uplift, exhumation, and plateau growth in the Red River region, Yunnan Province, China, Geol. Soc. Am. Bull., 116, 895-909, 2004.

Schumm, S. A.: Evolution of drainage systems and slopes in badlands at Perth Amboy, New Jersey, Geol. Soc. Am. Bull., 67, 597-646, 1956.

Schwanghart, W. and Kuhn, N. J.: TopoToolbox: a set of Matlab functions for topographic analysis, Environ. Modell. Softw., 25, 770-781, 2010.

Scotti, V., Molin, P., Faccenna, C., Soligo, M., and Casas-Sainz, A.: The influence of surface and tectonic processes on landscape evolution of the Iberian Chain (Spain): quantitative geomorpholog- ical analysis and geochronology, Geomorphology, 206, 37-57, 2014.

Shahzad, F. and Gloaguen, R.: TecDEM: a MATLAB based toolbox for tectonic geomorphology, Part 1: Drainage network preprocessing and stream profile analysis, Comput. Geosci., 37, 250 260, 2011a.

Shahzad, F. and Gloaguen, R.: TecDEM: a MATLAB based toolbox for tectonic geomorphology, Part 2: Surface dynamics and basin analysis, Comput. Geosci., 37, 261-271, 2011 b.

Siddiqui, S. and Soldati, M.: Appraisal of active tectonics using DEM-based hypsometric integral and trend surface analysis in Emilia-Romagna Apennines, northern Italy, Turk. J. Earth Sci., 23, 277-292, doi:10.3906/yer-1306-12, 2014.

Singh, S. K., Rodríguez, M., and Espindola, J. M.: A catalog of shallow earthquakes of Mexico from 1900 to 1981, B. Seismol. Soc. Am., 74, 267-279, 1984.

Smith, M. W.: Roughness in the Earth Sciences, Earth Sci. Rev., 136, 202-225, doi:10.1016/j.earscirev.2014.05.016, 2014.

Snyder, N. P., Whipple, K. X., Tucker, G. E., and Merritts, D. J.: Landscape response to tectonic forcing: digital elevation model analysis of stream profiles in the Mendocino triple junction region, northern California, Geol. Soc. Am. Bull., 112, 1250-1263, 2000.

Sofia, G., Pirotti, F., and Tarolli, P.: Variations in multiscale curvature distribution and signatures of LiDAR DTMs errors, Earth Surf. Proc. Land., 38, 1116-1134, 2013.

Sofia, G., Dalla Fontana, G., and Tarolli, P.: High-resolution topography and anthropogenic feature extraction: testing geomorphometric parameters in floodplains, Hydrol. Process., 28, 20462061, 2014.

Steiner, M. B. and Walker, J. D.: Late Silurian plutons in Yucatan, J. Geophys. Res., 101, 17727-17735, doi:10.1029/96JB00174, 1996.

Strahler, A. N.: Hypsometric (area-altitude) analysis of erosional topography, Geol. Soc. Am. Bull., 63, 1117-1142, 1952.

Strahler, A. N.: Quantitative analysis of watershed geomorphology, Transactions of the American Geophysical Union, 8, 913-920, 1957.

Tarolli, P., Sofia, G., and Dalla Fontana, G.: Geomorphic features extraction from high-resolution topography: landslide crowns and bank erosion, Nat. Hazards, 61, 65-83, 2012.

Telbisz, T., Kovács, G., Székely, B., and Szabó, J.: Topographic swath profile analysis: a generalization and sensitivity evaluation of a digital terrain analysis tool, Z. Geomorph., 57, 485-513, doi:10.1127/0372-8854/2013/0110, 2013.

Troiani, F. and Della Seta, M.: The use of the Stream LengthGradient index in morphotectonic analysis of small catchments: a case study from Central Italy, Geomorphology, 102, 159-168, doi:10.1016/j.geomorph.2007.06.020, 2008.

Turner, H. L., LaFemina, P., Saballos, A., Mattioli, G. S., Jansma, P. E., and Dixon, T.: Kinematics of the Nicaraguan forearc from GPS geodesy, Geophys. Res. Lett., 34, L02302, doi:10.1029/2006GL027586, 2007.

Wawrzyniec, T., Molina-Garza, R. S., Geissman, J., and Iriondo, A.: A newly discovered, relic, transcurrent plate boundary: the Tonala shear zone and paleomagnetic evaluation of the western Maya block, SW Mexico, Geological Society of America, Annual Meeting, Salt Lake City, USA, 16-19 October 2005, Abstracts with Programs, 37, p. 68, 2005. 
Weber, B., Cameron, K. L., Osorio, M., and Schaaf, P.: A Late Permian tectonothermal event in Grenville crust of the southern Maya Terrane: U-Pb zircon ages from the Chiapas Massif, southeastern Mexico, Int. Geol. Rev., 47, 509-529, 2005.

Weber, B., Iriondo, A., Premo, W., Hecht, L., and Schaaf, P.: New insights into the history and origin of the southern Maya block, SE Mexico: U-Pb-SHRIMP zircon geochronology from metamorphic rocks of the Chiapas massif, Int. J. Earth Sci., 96, 253269, 2007.

Weidie, A. E.: Lineaments of the Yucatan Peninsula and fractures of the Central Quintana Roo coast, in: Field Trip No. 10 - Yucatan, Road Log and Supplement to 1978 Guidebook, GSA annual meeting, New Orleans, Louisiana, 18-21 October 1982, $21-$ 25, 1982.

Weidie, A. E.: Geology of Yucatan platform, in: Geology and Hydrogeology of the Yucatan and Quaternary Geology of Northeastern Yucatan Peninsula, edited by: Ward, W. C., Weidie, A. E., and Back, W., New Orleans Geol. Soc., New Orleans, Louisiana, $1-19,1985$.

White, R. A.: Catalog of historic seismicity in the vicinity of the Chixoy-Polochic and Motagua faults, Guatemala, Open-File Report 84-88, US Geological Survey, Office of Earthquakes, Volcanoes and Engineering, Menlo Park, California, USA, 1-26, 1984.
Whittaker, A. C., Attal, M., Cowie, P. A., Tucker, G. E., and Roberts, G.: Decoding temporal and spatial patterns of fault uplift using transient river long profiles, Geomorphology, 100, 506526, 2008.

Willett, S. and Brandon, M.: On steady states in mountain belts, Geology, 30, 175-178, 2002.

Witt, C., Brichau, S., and Carter, A.: New constraints on the origin of the Sierra Madre de Chiapas (south Mexico) from sediment provenance and apatite thermochronometry, Tectonics, 31, TC6001, doi:10.1029/2012TC003141, 2012a.

Witt, C., Rangin, C., Andreani, L., Olaez, N., and Martínez, J.: The transpressive left-lateral Sierra Madre de Chiapas and its buried front in the Tabasco plain (Southern Mexico), J. Geol. Soc. London, 169, 143-155, 2012b.

Wobus, C., Whipple, K. X., Kirby, E., Snyder, N., Johnson, J., Spyropolou, K., Crosby, B., and Sheehan, D.: Tectonics from topography: procedures, promises and pitfalls, Geol. S. Am. S., 398, 55-74, 2006. 